\title{
System Evaluations and Life-Cycle Cost Analyses for High-Temperature Electrolysis Hydrogen Production Facilities
}

Edwin A. Harvego James E. O'Brien Michael G. McKellar

May 2012

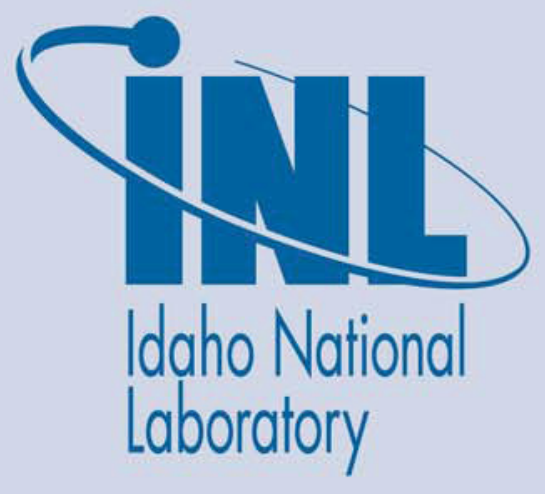

The INL is a U.S. Department of Energy National Laboratory operated by Battelle Energy Alliance 


\section{DISCLAIMER}

This information was prepared as an account of work sponsored by an agency of the U.S. Government. Neither the U.S. Government nor any agency thereof, nor any of their employees, makes any warranty, expressed or implied, or assumes any legal liability or responsibility for the accuracy, completeness, or usefulness, of any information, apparatus, product, or process disclosed, or represents that its use would not infringe privately owned rights. References herein to any specific commercial product, process, or service by trade name, trade mark, manufacturer, or otherwise, does not necessarily constitute or imply its endorsement, recommendation, or favoring by the U.S. Government or any agency thereof. The views and opinions of authors expressed herein do not necessarily state or reflect those of the U.S. Government or any agency thereof. 


\title{
System Evaluations and Life-Cycle Cost Analyses for High-Temperature Electrolysis Hydrogen Production Facilities
}

\author{
Edwin A. Harvego, James E. O’Brien, Michael G. McKellar
}

May 2012

Idaho National Laboratory Idaho Falls, Idaho 83415

http://www.inl.gov

Prepared for the

U.S. Department of Energy

Office of Nuclear Energy

Under DOE Idaho Operations Office

Contract DE-AC07-05ID14517 


\section{ABSTRACT}

This report presents results of system evaluations and lifecycle cost analyses performed for several different commercial-scale high-temperature electrolysis (HTE) hydrogen production concepts. The concepts presented in this report rely on grid electricity and non-nuclear high-temperature process heat sources for the required energy inputs. The HYSYS process analysis software was used to evaluate both central plant designs for large-scale hydrogen production $(50,000 \mathrm{~kg}$ /day or larger) and forecourt plant designs for distributed production and delivery at about $1,500 \mathrm{~kg} /$ day. The HYSYS software inherently ensures mass and energy balances across all components and it includes thermodynamic data for all chemical species. The optimized designs described in this report are based on analyses of process flow diagrams that included realistic representations of fluid conditions and component efficiencies and operating parameters for each of the HTE hydrogen production configurations analyzed. As with previous HTE system analyses performed at the INL, a custom electrolyzer model was incorporated into the overall process flow sheet. This electrolyzer model allows for the determination of the average Nernst potential, cell operating voltage, gas outlet temperatures, and electrolyzer efficiency for any specified inlet steam, hydrogen, and sweep-gas flow rates, current density, cell active area, and external heat loss or gain.

The lifecycle cost analyses were performed using the H2A analysis methodology developed by the Department of Energy (DOE) Hydrogen Program. This methodology utilizes spreadsheet analysis tools that require detailed plant performance information (obtained from HYSYS), along with financial and cost information to calculate lifecycle costs. There are standard default sets of assumptions that the methodology uses to ensure consistency when comparing the cost of different production or plant design options. However, these assumptions may also be varied within the spreadsheets when better information is available or to allow the performance of sensitivity studies.

The selected reference plant design for this study was a $1500 \mathrm{~kg} /$ day forecourt hydrogen production plant operating in the thermal-neutral mode. The plant utilized industrial natural gas-fired heaters to provide process heat, and grid electricity to supply power to the electrolyzer modules and system components. Modifications to the reference design included replacing the gas-fired heaters with electric resistance heaters, changing the operating mode of the electrolyzer (to operate below the thermal-neutral voltage), and considering a larger $50,000 \mathrm{~kg}$ /day central hydrogen production plant design. Total H2Acalculated hydrogen production costs for the reference $1,500 \mathrm{~kg} /$ day forecourt hydrogen production plant were $\$ 3.12 / \mathrm{kg}$. The all-electric plant design using electric resistance heaters for process heat, and the reference design operating below the thermal-neutral voltage had calculated lifecycle hydrogen productions costs of $\$ 3.26 / \mathrm{kg}$ and $\$ 4.89 / \mathrm{kg}$, respectively. Because of its larger size and associated economies of scale, the $50,000 \mathrm{~kg}$ /day central hydrogen production plant was able to produce hydrogen at a cost of only $\$ 2.68 / \mathrm{kg}$. 


\section{CONTENTS}

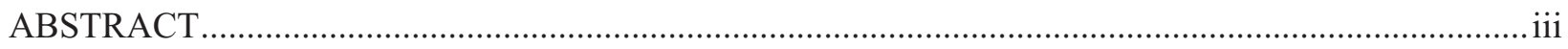

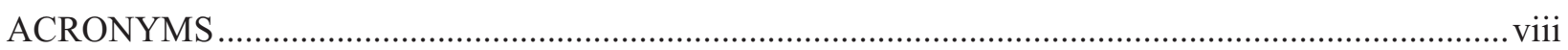

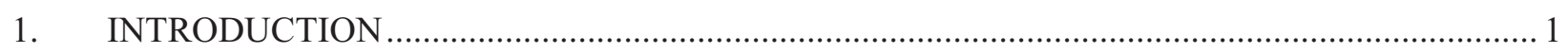

2. REFERENCE FORECOURT HYDROGEN PRODUCTION PLANT ............................................ 2

2.1 Process Flow Diagram for the Reference HTE Plant Design ............................................ 2

2.2 Results of Reference Plant Process Analysis ....................................................................... 4

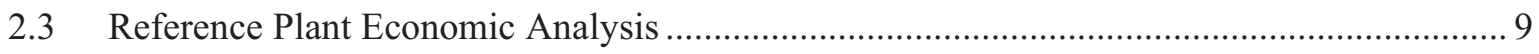

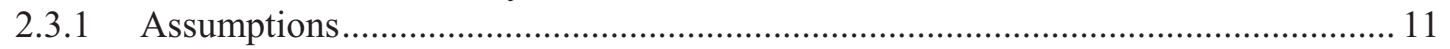

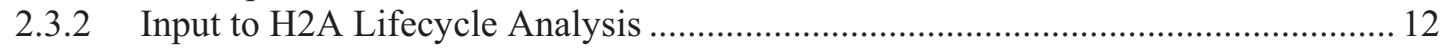

2.3.3 Results of lifecycle analysis for reference forecourt design .................................... 19

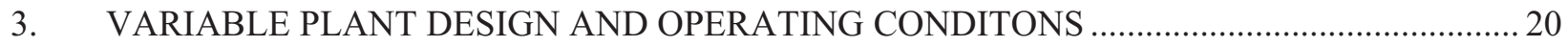

3.1 All Electric 1500 kg/day Hydrogen Production Plant........................................................ 20

3.1.1 Economic Analysis of All-Electric 1500 kg/day Hydrogen Production Plant.......... 21

3.2 Reference $1500 \mathrm{~kg} /$ day Hydrogen Production Plant Operating below the Thermal-

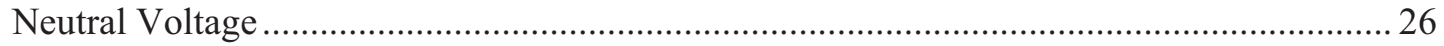

3.2.1 Economic Analysis of the Reference $1500 \mathrm{~kg} /$ day Hydrogen Production Plant Operating below Thermal-Neutral Voltage .................................................... 30

3.3 Large 50,000 kg/day Central Hydrogen Production Plant ............................................... 35

3.3.1 Economic Analysis of Large 50,000 kg/day Central Hydrogen Production

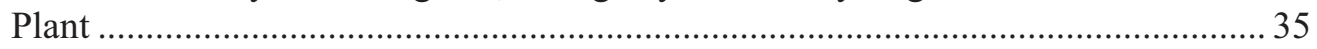

3.3.2 Results of lifecycle analysis for large central hydrogen production plant ................. 44

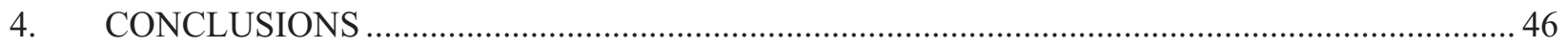

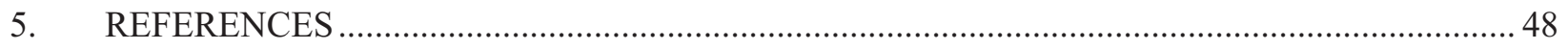

\section{FIGURES}

Figure 1. Process flow diagram for reference forecourt $1500 \mathrm{~kg} /$ day hydrogen production plant. .............. 3

Figure 2. Process flow diagram for all electric $1500 \mathrm{~kg}$ /day hydrogen production plant........................2 21

Figure 3. Process flow diagram for reference $1500 \mathrm{~kg}$ /day hydrogen production plant operating

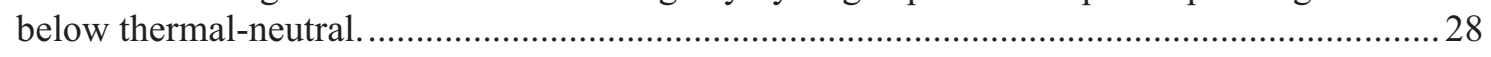

Figure 4. Process flow diagram for reference $50,000 \mathrm{~kg} /$ day hydrogen production plant........................ 36

\section{TABLES}

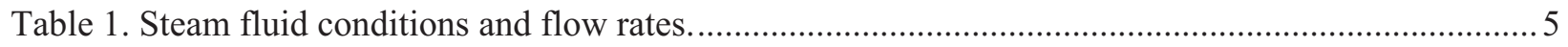

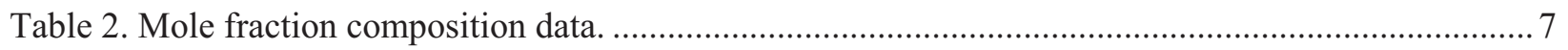

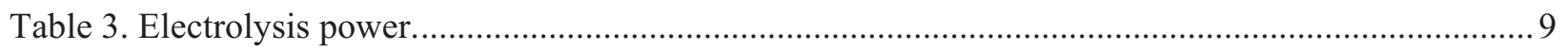




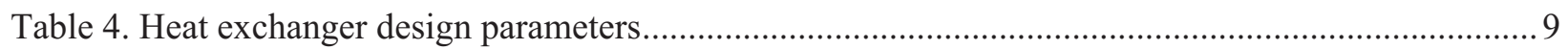

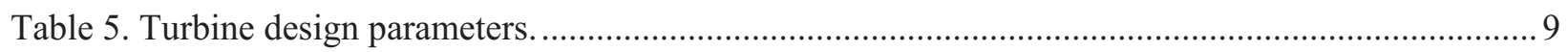

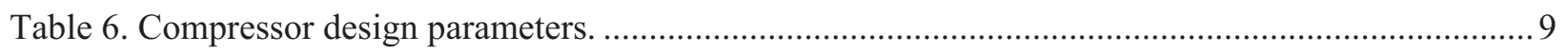

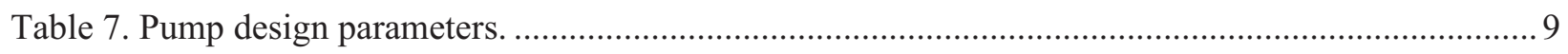

Table 8. Basic financial assumptions for base HTE forecourt design. ................................................... 13

Table 9. Reference plant direct depreciable capital costs. .................................................................... 14

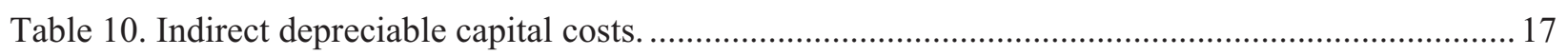

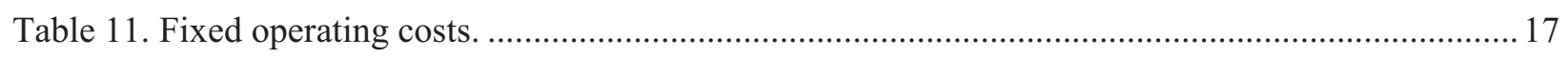

Table 12. Variable operating energy feedstock and utility requirements and costs in startup year............ 18

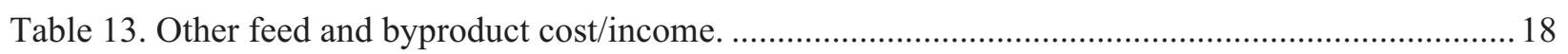

Table 14. Total feed, utility, and byproduct variable costs for reference forecourt hydrogen production plant.

Table 15. Hydrogen production and delivery cost summary for reference $1500 \mathrm{~kg}$ /day hydrogen

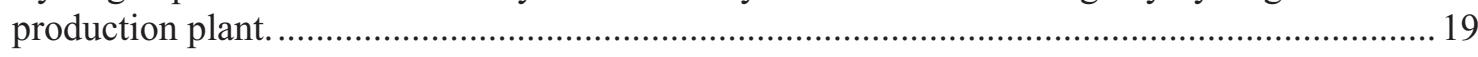

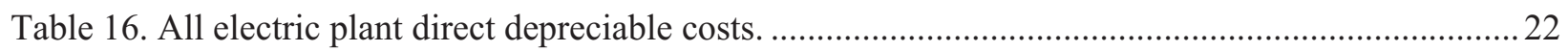

Table 17. Comparison of feed and utility costs for reference and all-electric hydrogen plant designs.

Table 18. Hydrogen production and delivery cost summary for all-electric $1500 \mathrm{~kg} /$ day hydrogen

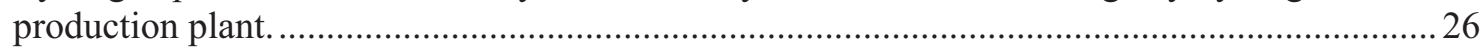

Table 19. Comparison of selected hydrogen production loop conditions for operation at and

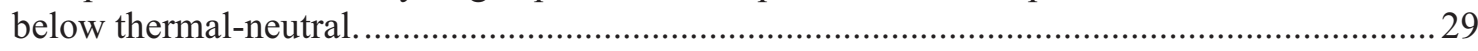

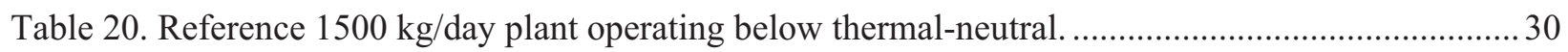

Table 21. Comparison of feed and utility costs for reference hydrogen production plant operating at and below thermal-neutral.

Table 22. Hydrogen production and delivery cost summary for all-electric $1500 \mathrm{~kg} /$ day reference

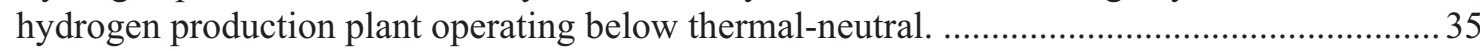

Table 23. Basic financial assumptions for HTE central plant design. ..................................................... 37

Table 24. Large central plant direct depreciable capital costs. .............................................................. 38

Table 25. Large central plant Indirect depreciable costs....................................................................... 42

Table 26. Fixed operating costs for large central hydrogen production plant........................................... 42

Table 27. Variable central plant operating energy feedstock and utility requirements and costs in

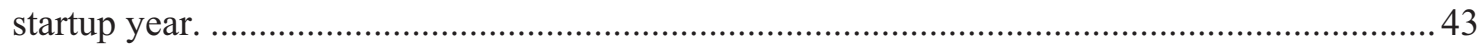

Table 28. Other central hydrogen production feed and byproduct cost/income. .................................... 43

Table 29. Total feed, utility, and byproduct variable costs for large central hydrogen production plant.

Table 30. Hydrogen production cost summary for large central hydrogen production plant without

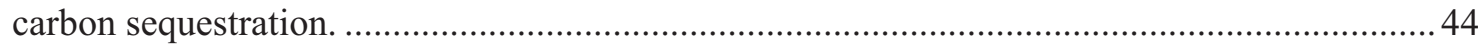

Table 31. Summary of carbon sequestration costs for central hydrogen production plant. .45 
Table 32. Hydrogen production cost summary for large central hydrogen production plant with carbon sequestration.

Table 33. Summary of HTE hydrogen production plant operating conditions and life cycle analyses..... 


\section{ACRONYMS}

$\begin{array}{ll}\mathrm{CO} & \text { Carbon Monoxide } \\ \mathrm{CO}_{2} & \text { Carbon Dioxide } \\ \mathrm{DCF} & \text { Discounted Cash Flow } \\ \text { DOE } & \text { Department of Energy } \\ \mathrm{HTE} & \text { High-Temperature Electrolysis } \\ \mathrm{HYSYS} & \text { Process analysis software developed by Aspen Tech } \\ \mathrm{H}_{2} & \text { Hydrogen } \\ \mathrm{H} 2 \mathrm{~A} & \text { Hydrogen Analysis } \\ \mathrm{HX} & \text { Heat Exchanger } \\ \mathrm{INL} & \text { Idaho National Laboratory } \\ \text { IRR } & \text { Internal Rate of Return } \\ \text { MACRS } & \text { Modified Accelerated Cost Recovery System } \\ \text { O\&M } & \text { Operation and maintenance } \\ \mathrm{O}_{2} & \text { Oxygen } \\ \text { SOE } & \text { Solid Oxide Electrolyzer }\end{array}$




\section{INTRODUCTION}

This report presents results of system evaluations and lifecycle cost analyses performed for several different commercial-scale high-temperature electrolysis (HTE) hydrogen production concepts. The primary advantage of high temperature electrolysis over conventional electrolysis, which is a well established technology, is that considerably higher overall efficiencies can be achieved. The improved performance of HTE compared with conventional low-temperature (alkaline or PEM) electrolysis is directly related to the high temperature operation, which influences both the thermodynamics and electrochemical kinetics of the process. From thermodynamics, the electrical energy required for water or steam electrolysis decreases with increasing temperature, while the thermal energy requirement increases. Consequently, at higher temperatures, a larger fraction of the total electrolysis energy input can be supplied in the form of heat, increasing the overall process efficiency. In terms of electrochemical kinetics, activation and ohmic over-potentials also decrease dramatically with temperature.

The HYSYS process analysis software was used in the analysis of the HTE hydrogen production processes. Several different plant configurations and hydrogen production rates were evaluated, assuming both central plant designs for large-scale hydrogen production $(50,000 \mathrm{~kg} /$ day or larger) and forecourt plant designs for distributed production and delivery at about $1,500 \mathrm{~kg} /$ day. The HYSYS process analysis software inherently ensures mass and energy balances across all components and it includes thermodynamic data for all chemical species. The optimized designs described in this report are based on analyses of process flow diagrams that included realistic representation of fluid conditions and component efficiencies and operating parameters for each of the HTE hydrogen production configurations analyzed. As with previous HTE system analyses performed at the INL, a custom electrolyzer model was incorporated into the overall process flow sheet. This electrolyzer model allows for the determination of the average Nernst potential, cell operating voltage, gas outlet temperatures, and electrolyzer efficiency for any specified inlet steam, hydrogen, and sweep-gas flow rates, current density, cell active area, and external heat loss or gain.

The lifecycle cost analyses were performed using the H2A analysis methodology developed by the Department of Energy (DOE) Hydrogen Program. This methodology utilizes spreadsheet analysis tools that requires detailed plant performance information (obtained from HYSYS), along with financial and cost information to calculate lifecycle costs. There are standard default sets of assumptions (discussed later) that the methodology uses to ensure consistency when comparing the cost of different production or plant design options. However, these assumptions may also be varied within the spreadsheet when better information is available or to allow the performance of sensitivity studies. Two H2A analysis spreadsheets were generated for this work: one Microsoft Excel spreadsheet to analyze central hydrogen production technologies and another to analyze forecourt hydrogen production technologies. The two models are very similar; the primary difference is that the central plant model performs carbon sequestration calculations, whereas the forecourt plant model performs refueling station compression, storage, and dispensing calculations.

The following sections of this report begin with a description of the base or reference HTE design concept for a $1,500 \mathrm{~kg} /$ day forecourt hydrogen production design along with operating conditions and performance parameters used to develop the lifecycle cost estimate. The reference plant design utilized industrial natural gas-fired heaters to provide process heat, and grid-supplied electricity to provide power to the electrolyzer modules and system components. Required inputs for the lifecycle cost estimate are then presented, along with the results of the estimated hydrogen production cost ( $\$ \mathrm{~kg}$ of hydrogen). Subsequent sections of this report describe modifications to the design that included replacing the gas fired heaters with electric resistance heaters, changing the operating mode of the electrolyzer, and development of a larger $50,000 \mathrm{~kg} /$ day central hydrogen production plant design. 


\section{REFERENCE FORECOURT HYDROGEN PRODUCTION PLANT}

As indicated above, the INL selected reference design for this study is a forecourt-scale $1,500 \mathrm{~kg} / \mathrm{day}$ HTE hydrogen production plant that uses natural gas-fired heaters to supply process heat and grid electricity to power the electrolysis process and system components. In this HTE process, hightemperature steam at $800^{\circ} \mathrm{C}$ and $5 \mathrm{MPa}$ is delivered to the cathode side of the electrolyzer where it is electrolytically reduced, producing hydrogen as a primary product and oxygen as a byproduct. The oxygen that is evolved on the anode side of the electrolyzer is removed using a steam sweep system. Residual steam is removed from both the hydrogen and oxygen streams exiting the electrolyzer by condensation to yield the dry hydrogen product and oxygen byproduct gases. For the reference design, the electrolyzer was operated in the thermal-neutral mode where the ohmic heating associated with the various stack resistance mechanisms equaled the endothermic cooling of the steam reduction process. This operating point results in a constant temperature adiabatic process that eliminats the need for heating or cooling of the electrolyzer. In addition, as described in the following section, the reference design utilized recuperative heat exchangers to minimize the required net high temperature process heat requirement, and to maximize overall hydrogen production efficiency.

\subsection{Process Flow Diagram for the Reference HTE Plant Design}

The HYSYS-generated process flow diagram for the reference HTE hydrogen production plant capable of producing 1,500 kg/day of hydrogen is shown in Figure 1. The process flow model was developed to include all the major components that would be present in the actual plant, including pumps, compressors, heat exchangers, and heaters. With realistic system boundary conditions and component efficiencies and operating parameters input to the process, HYSYS performed energy and mass balances to predict fluid conditions around the system, and resulting hydrogen and oxygen production rates.

In the process flow diagram shown in Figure 1, the processed water feedstock enters at the left in the diagram. The water is then raised to the HTE process pressure of 5.0 MPa in the liquid phase using a pump (Make-up Water Pump). Downstream of the pump, condensate from the water knockout tank is recycled back into the inlet stream at M3. The inlet water stream is then heated in Regenerator 1, which recovers heat from the post-electrolyzer hydrogen/steam outlet stream. Downstream of the regenerator, at the $\mathrm{H} 2 / \mathrm{H} 2 \mathrm{O}$ Mixer, the steam is mixed with recycled hydrogen product gas. A fraction of this product gas is recycled in this way in order to assure that reducing conditions are maintained on the steam/hydrogen electrodes in the HTE stacks. Downstream of the mixer, the inlet process steam/gas mixture enters Regenerator 2, where additional heat is recovered from the post-electrolyzer hydrogen/steam outlet stream. The inlet process stream then enters the natural gas-fired heater (Process HX 1) where final heating to the electrolysis operating temperature of $800^{\circ} \mathrm{C}$ occurs. The inlet process stream then enters the electrolyzer, where oxygen is electrolytically removed from the steam, producing hydrogen and oxygen.

Downstream of the electrolyzer, the hydrogen - rich product stream flows back through the two regenerators described earlier where the product stream is cooled and the inlet process stream is preheated. The product stream is cooled further at the H2/Water Knockout Tank, where the majority of any residual steam is condensed and separated; yielding dry hydrogen product. The cooled product stream is split at T2 and a fraction of the product gas is recycled into the inlet process stream, as discussed previously. A recirculating blower (H2 Recirc) is required to repressurize the recycled hydrogen stream to the upstream pressure at $\mathrm{H} 2 / \mathrm{H} 2 \mathrm{O}$ Mixer.

The process flow diagram in Figure 1 also shows the steam sweep system used to remove the excess oxygen that is evolved on the anode side of the electrolyzer. The feed water is supplied to the steam sweep system and raised to the process operating pressure in the liquid phase by the Sweep Water pump (shown in the lower right portion of the flow diagram). This water is converted to steam in Regenerator 3 and then passed through the natural gas-fired heater (Process HX 2) where it is heated to the electrolysis 


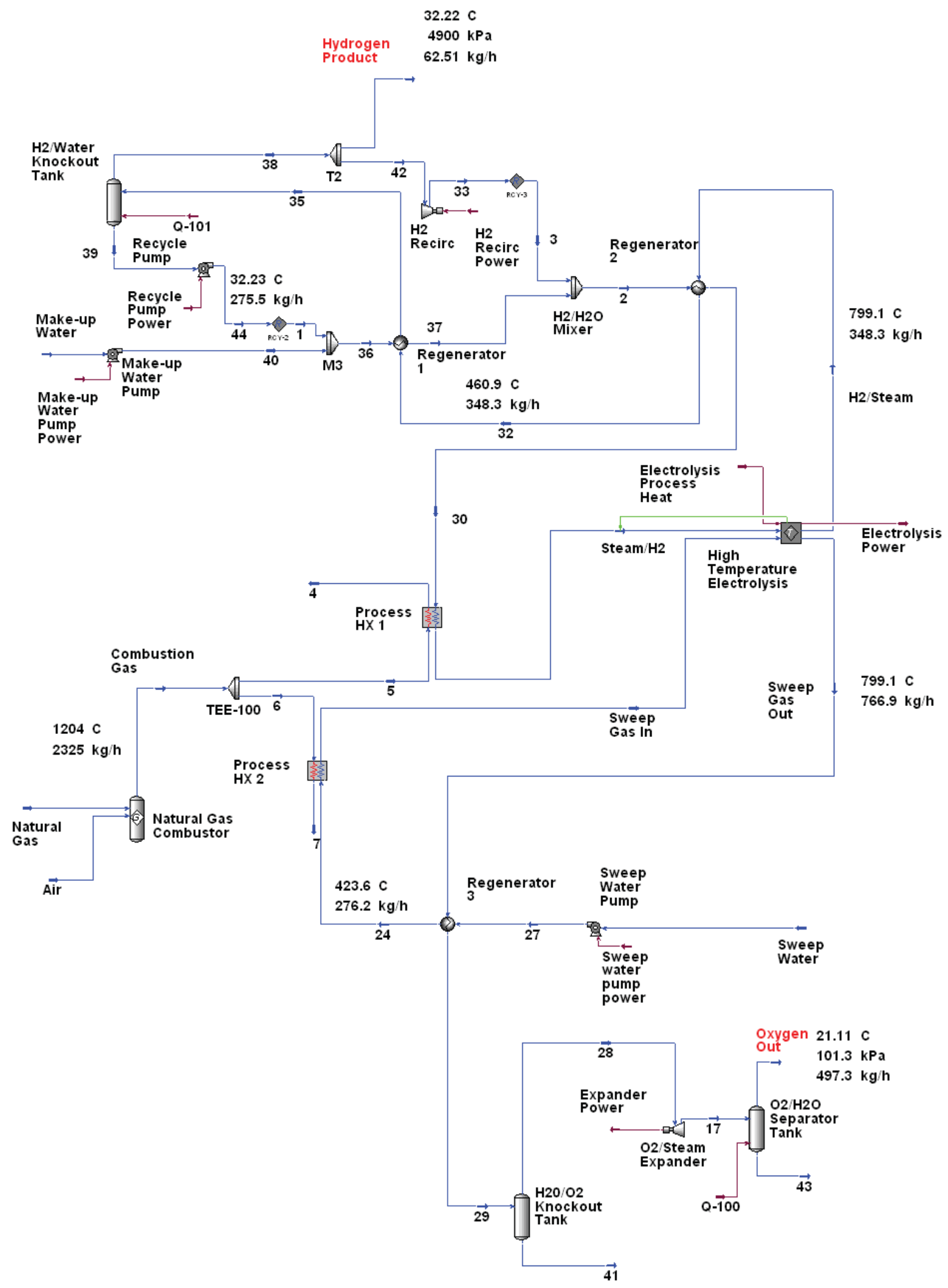

Figure 1. Process flow diagram for reference forecourt $1500 \mathrm{~kg} /$ day hydrogen production plant. 
operating temperature of $800^{\circ} \mathrm{C}$. The sweep steam then passes through the electrolyzer, taking with it the oxygen that has evolved on the anode side. The resulting steam/oxygen mixture (approximately 50\% oxygen) is then cooled and partially condensed by passing back through Regenerator 3 . The steam and oxygen mixture then passes through the $\mathrm{H} 2 \mathrm{O} / \mathrm{O} 2$ Knockout Tank where the condensate (approximately $20 \%$ of the moisture content) is removed before entering the O2/Steam Expander. The electric power produced in the expansion process is slightly higher than the total pumping requirements of the combined process and steam sweep loops. As a result, for this system configuration, the net electric power requirement for the total system is slightly less than the required electrical power of the electrolyzer alone. After leaving the expander, the remaining steam and oxygen mixture enters the $\mathrm{O} 2 / \mathrm{H} 2 \mathrm{O}$ Separator tank where the majority of any residual steam is condensed and separated; yielding dry oxygen byproduct.

The natural gas-fired heaters used in the HYSYS analysis were modeled assuming a Gibbs reaction model (Natural Gas Combustor) shown in the lower left portion of the process flow diagram. Since this model assumes stoichiometric conditions for the combustion process, the ratio of air and natural gas flow rates was adjusted to give the desired combustion gas temperature of $2200^{\circ} \mathrm{F}\left(1204^{\circ} \mathrm{C}\right)$. The combined air and natural gas flow rate was then adjusted to provide the needed process heat to raise both the inlet steam/hydrogen process stream and sweep gas stream to the electrolyzer operating temperature $\left(800^{\circ} \mathrm{C}\right)$. Optimization of the two process heaters (Process HX 1 and Process HX 2) was achieved by controlling the distribution of the combustion gas stream delivered to each of the process heaters (at T3). For the reference design, the optimum distribution (assuming a minimum approach temperature of $25^{\circ} \mathrm{C}$ for each of the process heaters) resulted in approximately $89 \%$ of the combustion gas delivered to Process HX 1 and $11 \%$ to Process HX 2.

\subsection{Results of Reference Plant Process Analysis}

Figure 1 shows values of fluid conditions (temperature, pressure and mass flow rate) at various state points around the system. As noted earlier, the electrolyzer was operated in the thermal-neutral mode. A total of 10,420 electrolysis cells was required, each with an active cell area of $225 \mathrm{~cm}^{2}$. The cells were operated at a current density of $0.699 \mathrm{amps} / \mathrm{cm}^{2}$, with an area specific resistance of $0.2776 \mathrm{ohms}-\mathrm{cm}^{2}$ producing $1,500 \mathrm{~kg} /$ day $(62.5 \mathrm{~kg} / \mathrm{hr})$ of hydrogen at an operating temperature of $800^{\circ} \mathrm{C}$. The resulting electrolyzer efficiency (based on the lower heating value of hydrogen) is defined as:

$\eta(E)=\frac{L H V * m(H 2) * 100}{P(E)}$

where

$\eta(E)=$ electrolyzer hydrogen production efficiency (\%),

$\mathrm{LHV}^{*} \mathrm{~m}(\mathrm{H} 2)=$ energy content of hydrogen product gas based on lower heating value,

$\mathrm{P}(\mathrm{E})=$ electrical power input to electrolyzer $(\mathrm{kW})$,

was calculated to be $97.6 \%$.

The overall facility hydrogen production efficiency, defined as:

$\eta(S)=\frac{L H V * m(H 2) * 100}{\sum P(\text { pumps })+P(\text { circ })-P(\text { expand })+P(E)+L H V * m(N G)}$

where

$\eta(S)=$ facility hydrogen production efficiency,

$\sum \mathrm{P}($ pumps $)=$ electric power input to all pumps in the system $(\mathrm{kW})$,

$\mathrm{P}(\mathrm{circ})=$ electric power input to helium circulator $(\mathrm{kW})$, 
$\mathrm{P}($ expand $)=$ electric power produced by the O2/Steam Expander,

$\mathrm{LHV}^{*} \mathrm{~m}(\mathrm{NG})=$ energy content of natural gas feed based on lower heating value $(\mathrm{kW})$,

was calculated to be $69.5 \%$.

As noted earlier, the relatively high overall system hydrogen production efficiency was in part achieved because the O2/Steam Expander produced more power than was required to drive the other components in the process and steam sweep loops. As a result, the steam expander power recovery contributed about $3 \%$ of the electric power required for the electrolysis process, resulting in a fractional reduction in the electric power supplied from the grid.

The H2A economic analysis methodology discussed in subsequent sections of this report requires detailed information on plant design and performance in order to calculate lifecycle costs. Therefore, in addition to the general information on fluid conditions provided in Figure 1, this section provides detailed information on stream conditions and component design and performance that form the basis for input to the H2A lifecycle cost analyses. Fluid conditions, flow rates, steam composition and component operating parameters for the optimized reference design are summarized in Tables 1 through 7 at each of the locations shown in Figure 1. The pressure, temperature, mass flow rates, and the vapor fraction for each stream are displayed in Table 1. The composition of each stream is shown in Table 2. The Electrolysis power is provided in Table 3, and the thermal duty, overall heat transfer coefficient, UA, logmean temperature difference (LMTD), and the minimum approach temperature for each heat exchanger is found in Table 4. Turbine, compressor and pump parameters are given in Tables 5 through 7 , respectively.

Table 1. Steam fluid conditions and flow rates.

\begin{tabular}{|l|l|l|l|l|}
\hline Name & $\begin{array}{l}\text { Pressure } \\
{[\mathbf{k P a}]}\end{array}$ & $\begin{array}{l}\text { Temperature } \\
{[\mathbf{C}]}\end{array}$ & $\begin{array}{l}\text { Mass Flow } \\
{[\mathbf{k g} / \mathbf{h}]}\end{array}$ & $\begin{array}{l}\text { Vapor / Phase } \\
\text { Fraction }\end{array}$ \\
\hline $\mathbf{1}$ & 5000 & 32.2312 & 275.477 & 0 \\
\hline $\mathbf{1 7}$ & 101.325 & 68.6428 & 662.237 & 0.868967 \\
\hline $\mathbf{2}$ & 4980 & 153.093 & 838.956 & 0.111451 \\
\hline $\mathbf{2 4}$ & 4960 & 423.567 & 276.232 & 1 \\
\hline $\mathbf{2 7}$ & 4966.89 & 21.5263 & 276.232 & 0 \\
\hline $\mathbf{2 8}$ & 4933.11 & 204.199 & 662.237 & 1 \\
\hline $\mathbf{2 9}$ & 4933.11 & 204.199 & 766.9 & 0.810805 \\
\hline $\mathbf{3}$ & 4980 & 34.1635 & 10.3213 & 1 \\
\hline $\mathbf{3 0}$ & 4960 & 232.492 & 838.956 & 0.261569 \\
\hline $\mathbf{3 2}$ & 4920 & 460.933 & 348.288 & 1 \\
\hline $\mathbf{3 3}$ & 4980 & 34.1635 & 10.3028 & 1 \\
\hline $\mathbf{3 5}$ & 4900 & 188.319 & 348.288 & 0.959356 \\
\hline
\end{tabular}




\begin{tabular}{|c|c|c|c|c|}
\hline 36 & 5000 & 21.3686 & 828.634 & 0 \\
\hline 37 & 4980 & 164.3 & 828.634 & 0 \\
\hline 38 & 4900 & 32.2222 & 72.8112 & 1 \\
\hline 39 & 4900 & 32.2222 & 275.477 & 0 \\
\hline 4 & 81.353 & 257.483 & 2065.67 & 1 \\
\hline 40 & 5000 & 15.9608 & 553.158 & 0 \\
\hline 41 & 4933.11 & 204.199 & 104.662 & 0 \\
\hline 42 & 4900 & 32.2222 & 10.3028 & 1 \\
\hline 43 & 101.325 & 21.1111 & 164.975 & 0 \\
\hline 44 & 5000 & 32.2312 & 275.477 & 0 \\
\hline 5 & 101.353 & 1204.43 & 2065.67 & 1 \\
\hline 6 & 101.353 & 1204.43 & 259.633 & 1 \\
\hline 7 & 81.353 & 448.562 & 259.633 & 1 \\
\hline 8 & 81.353 & 21.1111 & 259.633 & 0.928308 \\
\hline 9 & 81.353 & 21.1111 & 2065.67 & 0.928308 \\
\hline Air & 101.353 & 21.1111 & 2259.45 & 1 \\
\hline Combustion Gas & 101.353 & 1204.43 & 2325.3 & 1 \\
\hline H2/Steam & 4940 & 799.111 & 348.288 & 1 \\
\hline $\begin{array}{l}\text { Hydrogen } \\
\text { Product }\end{array}$ & 4900 & 32.2222 & 62.5084 & 1 \\
\hline Make-up Water & 101.325 & 15.5556 & 553.158 & 0 \\
\hline Natural Gas & 101.353 & 21.1111 & 65.8571 & 1 \\
\hline Normalized flow & 101.325 & 0 & 65.8571 & 1 \\
\hline Null Stream & 101.353 & 1204.43 & 0 & 0 \\
\hline Oxygen Out & 101.325 & 21.1111 & 497.263 & 1 \\
\hline Steam/H2 & 4940 & 800 & 838.956 & 1 \\
\hline
\end{tabular}




\begin{tabular}{|l|l|l|l|l|}
\hline Sweep Gas In & 4940 & 800 & 276.232 & 1 \\
\hline Sweep Gas Out & 4940 & 799.111 & 766.9 & 1 \\
\hline Sweep Water & 101.325 & 21.1111 & 276.232 & 0 \\
\hline
\end{tabular}

Table 2. Mole fraction composition data.

\begin{tabular}{|c|c|c|c|c|c|c|c|}
\hline Name & Water & Hydrogen & Oxygen & Nitrogen & $\mathrm{CO} 2$ & NO & Methane \\
\hline 1 & 1.000 & 0.000 & - & - & - & - & - \\
\hline 2 & 0.901 & 0.099 & - & - & - & - & - \\
\hline 3 & 0.001 & 0.999 & - & - & - & - & - \\
\hline 4 & 0.100 & - & 0.099 & 0.741 & 0.050 & 0.001 & - \\
\hline 5 & 0.100 & - & 0.099 & 0.741 & 0.050 & 0.001 & - \\
\hline 6 & 0.100 & - & 0.099 & 0.741 & 0.050 & 0.001 & - \\
\hline 7 & 0.100 & - & 0.099 & 0.741 & 0.050 & 0.001 & - \\
\hline 8 & 0.100 & - & 0.099 & 0.741 & 0.050 & 0.001 & - \\
\hline 9 & 0.100 & - & 0.099 & 0.741 & 0.050 & 0.001 & - \\
\hline 17 & 0.384 & - & 0.616 & - & - & - & - \\
\hline 24 & 1.000 & - & - & - & - & - & - \\
\hline 27 & 1.000 & - & - & - & - & - & - \\
\hline 28 & 0.384 & - & 0.616 & - & - & - & - \\
\hline 29 & 0.500 & - & 0.500 & - & - & - & - \\
\hline 30 & 0.901 & 0.099 & - & - & - & - & - \\
\hline 32 & 0.300 & 0.700 & - & - & - & - & - \\
\hline 33 & 0.001 & 0.999 & - & - & - & - & - \\
\hline 35 & 0.300 & 0.700 & - & - & - & - & - \\
\hline
\end{tabular}




\begin{tabular}{|c|c|c|c|c|c|c|c|}
\hline 36 & 1.000 & - & - & - & - & - & - \\
\hline 37 & 1.000 & - & - & - & - & - & - \\
\hline 38 & 0.001 & 0.999 & - & - & - & - & - \\
\hline 39 & 1.000 & 0.000 & - & - & - & - & - \\
\hline 40 & 1.000 & - & - & - & - & - & - \\
\hline 41 & 0.998 & - & 0.002 & - & - & - & - \\
\hline 42 & 0.001 & 0.999 & - & - & - & - & - \\
\hline 43 & 1.000 & - & - & - & - & - & - \\
\hline 44 & 1.000 & 0.000 & - & - & - & - & - \\
\hline Air & - & - & 0.210 & 0.780 & - & - & - \\
\hline Combustion Gas & 0.100 & - & 0.099 & 0.741 & 0.050 & 0.001 & - \\
\hline H2/Steam & 0.300 & 0.700 & - & - & - & - & - \\
\hline $\begin{array}{l}\text { Hydrogen } \\
\text { Product }\end{array}$ & 0.001 & 0.999 & - & - & - & - & - \\
\hline Make-up Water & 1.000 & - & - & - & - & - & - \\
\hline Natural Gas & - & - & - & - & - & - & 1.000 \\
\hline Normalized flow & - & - & - & - & - & - & 1.000 \\
\hline Null Stream & 0.100 & - & 0.099 & 0.741 & 0.050 & 0.001 & - \\
\hline Oxygen Out & 0.024 & - & 0.976 & - & - & - & - \\
\hline Steam/H2 & 0.901 & 0.099 & - & - & - & - & - \\
\hline Sweep Gas In & 1.000 & - & - & - & - & - & - \\
\hline Sweep Gas Out & 0.500 & - & 0.500 & - & - & - & - \\
\hline Sweep Water & 1.000 & - & - & - & - & - & - \\
\hline
\end{tabular}


Table 3. Electrolysis power.

\begin{tabular}{|l|l|}
\hline Name & Heat Flow $(\mathbf{k W})$ \\
\hline Electrolysis Power & 2114 \\
\hline
\end{tabular}

Table 4. Heat exchanger design parameters

\begin{tabular}{|l|l|l|l|l|}
\hline Name & Duty [kJ/h] & UA [kJ/C-h] & LMTD [C] & $\begin{array}{l}\text { Minimum } \\
\text { Approach [C] }\end{array}$ \\
\hline Regenerator 1 & 521293 & 2567.29 & 203.052 & 149.15 \\
\hline Regenerator 2 & 578076 & 1383.69 & 417.777 & 24.99 \\
\hline Regenerator 3 & 879019 & 8664.13 & 101.455 & 25.00 \\
\hline Process HX 1 & $2.38464 \mathrm{E}+06$ & 10250.4 & 232.64 & 24.99 \\
\hline Process HX 2 & 243135 & 1714.53 & 141.809 & 24.995 \\
\hline
\end{tabular}

Table 5. Turbine design parameters.

\begin{tabular}{|l|l|l|l|}
\hline Name & Adiabatic Efficiency & Polytropic Efficiency & Power [kW] \\
\hline O2/Steam Expander & 80 & 77.4467 & 63.0452 \\
\hline
\end{tabular}

Table 6. Compressor design parameters.

\begin{tabular}{|l|l|l|}
\hline Name & $\begin{array}{l}\text { Adiabatic } \\
\text { Efficiency }\end{array}$ & Power $[\mathrm{kW}]$ \\
\hline H2 Recirc & 75 & 0.0786365 \\
\hline
\end{tabular}

Table 7. Pump design parameters.

\begin{tabular}{|l|l|l|l|}
\hline Name & $\begin{array}{l}\text { Adiabatic Efficiency } \\
{[\%]}\end{array}$ & Power [kW] & Pressure Head [m] \\
\hline Sweep Water Pump & 75 & 0.492736 & 491.115 \\
\hline Make-up Water Pump & 75 & 0.989366 & 492.437 \\
\hline Recycle Pump & 75 & 0.0101698 & 10.1642 \\
\hline
\end{tabular}

\subsection{Reference Plant Economic Analysis}

As noted earlier, the economic analysis of the reference plant design was performed using the $\mathrm{H} 2 \mathrm{~A}$ analysis methodology developed by the Department of Energy (DOE) Hydrogen Program. H2A, which stands for hydrogen analysis, was initiated in February 2003 to improve the transparency and consistency of the approach to analysis, to improve the understanding of the differences among analyses, and to seek better validation of analysis studies by industry. The objectives of H2A as defined by the DOE Hydrogen Program are to: 
1. Establish a standard format and list of parameters for reporting analysis results for central production, distributed (forecourt) production, and delivery.

2. Seek better validation of public analyses through dialog with industry.

3. Enhance understanding of the differences among publicly available analyses and make these differences more transparent.

4. Establish a mechanism for facile dissemination of public analysis results.

5. Work to reach consensus on specific analysis parameters for production and delivery.

The newest version of the H2A Production Model features enhanced usability and functionality. Input fields are consolidated and simplified. New capabilities include performing sensitivity analyses and scaling analyses to various plant sizes. As noted earlier the model is actually two models: one Microsoft Excel spreadsheet to analyze central hydrogen production technologies and another to analyze forecourt hydrogen production technologies. The two models are very similar; the primary difference is that the central model performs carbon sequestration calculations, whereas the forecourt model performs refueling station compression, storage, and dispensing calculations.

The standardized approach and set of assumptions for estimating the lifecycle cost of hydrogen production have been incorporated into a spreadsheet that was used for the economic analyses of the INL reference HTE design. This standardized spreadsheet provides a method of documenting information utilized in the performance of the economic analyses. The information incorporated in the spreadsheet includes:

- Original source(s) of all the data (i.e., report title, authors, etc.)

- Basic process information (feedstock and energy inputs, size of plant, co-products produced, etc.)

- Process flowsheet and stream summary (flowrate, temperature, pressure, composition of each stream)

- Technology performance assumptions (e.g., process efficiency and hydrogen product conditions)

- Economic assumptions (after tax internal rate of return, depreciation schedule, plant lifetime, income tax rate, capacity factor, etc.)

- Calculation of the discounted cash flow (the calculation procedure is built into the standardized spreadsheet so that all technologies use the same methodology)

- Results (plant-gate hydrogen selling price and cost contributions in $\$ / \mathrm{kg} \mathrm{H} 2$, operating efficiency, total fuel and feedstock consumption, and emissions)

- Sensitivity of the results to assumptions (e.g., feedstock cost, co-product selling price, capital cost, operating costs, internal rate of return, conversion efficiencies, etc.)

- Quantification of the level of uncertainty in the analysis.

The results of technology lifecycle costing exercises depend strongly on various financial assumptions. To facilitate a common basis for comparing alternative hydrogen production technologies, a standard set of assumptions were developed. These assumptions are delineated in the following section. 


\subsubsection{Assumptions}

As part of the H2A economic analysis methodology, a set of common cost assumptions were developed and incorporated into the analysis spreadsheet. The common cost assumptions were intended to be applied for all H2A Central and Forecourt supply options, but analysts can vary these assumptions to test the sensitivity of costs to the most critical assumptions. The set of base case assumptions used in the H2A methodology are:

- Analysis Methodology — Discounted Cash Flow (DCF) model that calculates a levelized H2 price that yields prescribed IRR

- Reference Financial Structure - 100\% equity with 10\% IRR - Include levelized H2 price plot for 0 to $25 \%$ IRR - Model allows debt financing

- Reference Year Dollars - adjusted at half-decade increments (e.g., 2005, 2010)

- Technology Development Stage - All Central and Forecourt cost estimates are based on mature, commercial facilities

- Inflation Rate $-1.9 \%$, but with resultant price of $\mathrm{H} 2$ in reference year constant dollars

- Income Taxes - 35\% Federal; 6\% State; 38.9\% Effective Property Taxes and Business Insurance $-2 \% /$ year of the total initial capital cost

- Sales Tax - Not included on basis that facilities and related purchases are wholesale and through a general contractor entity

- Working Capital Rate - $15 \%$ of the annual change in the total operating costs

- Analysis Period - 40 years for Central; 20 years for Forecourt

- Facility Life - 40 years for Central with case exceptions; 20 years for Forecourt with case exceptions

- Depreciation Type and Schedule for Initial Depreciable Capital Cost - MACRS - 20 years for Central with case exceptions; 7 years for Forecourt

- Construction Period and Cash Flow - Varies per case for Central; 0 for Forecourt

- Planned Replacement Capital — Post startup capital costs spread over time based on specific replacement estimates. Depreciation is based on MACRS schedule and 7 years or the same as the replacement period if it is shorter than 7 years.

- Unplanned Replacement Capital - Specified percentage of initial depreciable capital cost meant to handle unplanned replacement capital expenses that occur during an operating year of the plant. Depreciation is based on MACRS schedule and 7 years.

- Project Contingency — \% adjustment to the total initial capital cost such that the result represents the mean or expected cost value. Periodic replacement capital includes project contingency.

- Process Contingency - \% adjustment to the total initial capital cost such that the result incorporates the mean or expected overall performance.

- Land Cost - \$5000/acre purchased for Central; $\$ 0.5 / \mathrm{sqft} / \mathrm{month}$ for long-term lease for Forecourt

- Capacity Factor - 90\% for Central, with case exceptions; $70 \%$ for Forecourt with case exceptions 
- Average Burdened Labor Rate for Staff — \$50/hour for Central; $\$ 15 /$ hour for Forecourt

- G\&A Rate - $20 \%$ of the staff labor costs above

- Forecourt Maintenance and Repair - 5\%/yr of initial depreciable capital cost for small capacity and 3\%/yr for large capacity

- Co-produced and Cogenerated Electricity Price - \$30/MWh with sensitivities based on \$20/MWh low and \$50/MWh high

- $\mathrm{CO}_{2}$ incentive (when $\mathrm{CO}_{2}$ sequestration is not plausible) - not included in Base cases, sensitivity included at $\$ 100$ /tonne $\mathrm{C}\left(\$ 27.3 /\right.$ tonne $\left.\mathrm{CO}_{2}\right)$ for Central and Forecourt.

- $\mathrm{O}_{2}$ Credit - Not included in Base cases, sensitivity included at \$20/tonne for Central and Forecourt.

- Salvage Value - 10\% of initial capital, with case exceptions; $0 \%$ for Forecourt

- Decommissioning - 10\% of initial capital, with case exceptions; $0 \%$ for Forecourt

- Hydrogen Pressure at Central Gate - 300 psig. If higher pressure is inherent to the process, apply pumping power credit for pressure $>300$ psig.

- Central Storage - Buffer only as required for efficient operations

- Hydrogen Storage Pressure at Forecourt - 6250 psig

- Forecourt Compressed $\mathrm{H}_{2}$ Storage - $87.5 \%$ of maximum daily production (based on $35 \%$ of production divided by an assumed $40 \%$ dispensable hydrogen fraction)

- Hydrogen Purity - 98\% minimum; $\mathrm{CO}<10 \mathrm{ppm}$, sulfur $<10 \mathrm{ppm}$

- Sensitivity Variables and Ranges - Based on applying best judgment of $10 \%$ and $90 \%$ confidence limit extremes to the most significant baseline cost and performance parameters

The above assumptions along with basic process information calculated using the HYSYS model described in Section 2.1 were input to the H2A spreadsheet to calculate the lifecycle cost for the reference $1,500 \mathrm{~kg} /$ day forecourt hydrogen production plant design. The input to the spreadsheet and calculated lifecycle costs are described in more detail in the next two sections.

\subsubsection{Input to H2A Lifecycle Analysis}

Input for the H2A lifecycle cost analysis for the reference HTE design included plant performance and process information, financial data, and cost information (including capital, operating, maintenance, variable production, and replacement costs). As noted earlier, the plant performance and process information was obtained from the HYSYS model of the reference HTE design shown in Figure 1.

The financial information used in the spreadsheet was primarily based on the assumptions described in Section 2.3.1, but many of these values can also be changed by the user to perform sensitivities on the important financial assumptions. Plant-specific financial input by the user includes information like the construction time, plant startup date, plant design production capacity, plant operating capacity factor, capital expenditure rate during construction, and revenue and operating costs during startup. Table 8 shows selected financial input values used in the analysis of the reference $1,500 \mathrm{~kg} /$ day HTE forecourt plant design. In all of the tables that were extracted from the H2A spreadsheet, the tan cells represent values input by the user, blue cells represent H2A spreadsheet-calculated values, and green cells are used for comments or for other information that is not directly used in the lifecycle cost calculations. Most of the financial input for this study used the recommended guidelines of the H2A methodology discussed in Section 2.3.1. However, the assumed forecourt operating capacity in this study was assumed to be $85.2 \%$. The start-up date is 2020 with an assumed 1year construction period. 
Table 8. Basic financial assumptions for base HTE forecourt design.

\begin{tabular}{|c|c|}
\hline Reference year & 2010 \\
\hline Assumed start-up year & 2020 \\
\hline Length of Construction Period (years) & 1 \\
\hline$\%$ of Capital Spent in 1st Year of Construction & $100 \%$ \\
\hline$\%$ of Capital Spent in 2nd Year of Construction & $0 \%$ \\
\hline Start-up Time (years) & 0.5 \\
\hline Plant life (years) & 20 \\
\hline Analysis period (years) & 20 \\
\hline Depreciation Schedule Length (years) & 7 \\
\hline Depreciation Type & MACRS \\
\hline \% Equity Financing & $100 \%$ \\
\hline Interest rate on debt, if applicable (\%) & $0.00 \%$ \\
\hline Debt Period (years) & $\overline{0}$ \\
\hline$\%$ of Fixed Operating Costs During Start-up (\%) & $75 \%$ \\
\hline$\%$ of Revenues During Start-up (\%) & $50 \%$ \\
\hline$\%$ of Variable Operating Costs During Start-up (\%) & $50 \%$ \\
\hline Decommissioning costs (\% of depreciable capital investment) & $10 \%$ \\
\hline Salvage value (\% of total capital investment) & $10 \%$ \\
\hline Inflation rate $(\%)$ & $1.9 \%$ \\
\hline After-tax Real IRR (\%) & $10.0 \%$ \\
\hline State Taxes (\%) & $6.0 \%$ \\
\hline Federal Taxes (\%) & $35.0 \%$ \\
\hline Total Tax Rate (\%) & $38.90 \%$ \\
\hline WORKING CAPITAL (\% of yearly change in operating costs) & $15 \%$ \\
\hline
\end{tabular}

Plant capital cost information input by the user includes uninstalled and installed system and equipment costs, indirect depreciable capital costs (including site preparation, engineering and design, licensing and permitting, and associated contingencies), and non-depreciable capital costs (primarily the cost of the land for the plant site).

The system and equipment capital cost information for the reference plant design is summarized in Table 9. Uninstalled system and equipment costs were obtained from the references provided under "Data Source" in Column 6 of the table. For the most part, and installation cost factor of 4.11 was used to calculate installed equipment costs (Column 4) except as noted. For example, the installation cost factor for the Solid Oxide Electrolyzer (SOE) modules was assumed to be 1.8 since it is expected that the future design of these modules will be relatively simple and compact, allowing easy turnkey installation of multiple modules without significant installation costs. In effect, the 1.8 multiplier represents the cost of the completely assembled SOE module brought to the sight and installed at relatively low cost. The total 
installed cost of plant equipment obtained by summing the costs in Column 4 is $\$ 1,827,008$. This represents the total depreciable direct capital investment.

Table 9. Reference plant direct depreciable capital costs.

\begin{tabular}{|c|c|c|c|c|c|}
\hline $\begin{array}{c}\text { Major } \\
\text { pieces/systems } \\
\text { of equipment }\end{array}$ & $\begin{array}{c}\text { Baseline } \\
\text { Uninstalled } \\
\text { Costs }\end{array}$ & $\begin{array}{l}\text { Installation } \\
\text { Cost } \\
\text { Factor }\end{array}$ & $\begin{array}{c}\text { Baseline } \\
\text { Installed } \\
\text { Costs }\end{array}$ & Comments & $\begin{array}{c}\text { Data } \\
\text { Source }\end{array}$ \\
\hline $\begin{array}{l}\text { Water Supply } \\
\text { System }\end{array}$ & $\$ 30,368$ & 1.2 & $\$ 36,442$ & $\begin{array}{l}\text { The cost of } \\
\text { demineralized water } \\
\text { appears as a } \\
\text { feedstock cost in the } \\
\mathrm{H} 2 \mathrm{~A} \text { analysis. } \\
\text { Therefore, this cost is } \\
\text { for the waste water } \\
\text { treatment system } \\
\text { ratioed from } \\
\text { Dominion cost } \\
\text { estimate. Cost }= \\
\$ 500 \mathrm{~K} \times(62.5 \mathrm{~kg} \mathrm{per} \\
\mathrm{hr} / 6660 \mathrm{~kg} \text { per } \\
\mathrm{hr})^{\star *} 0.6=\$ 30,368\end{array}$ & Reference 7. \\
\hline $\begin{array}{l}\text { Make-Up Water } \\
\text { Pump }\end{array}$ & $\$ 46,100$ & 4.1 & $\$ 189,471$ & $\begin{array}{l}\text { Centrif., horiz., 8- } \\
\text { Stage, Horiz. Split } \\
\text { Case, } 2.0 \text { in dia disch } \\
\text { (min allowed) (553.2 } \\
\text { kg/hr; assume } \\
\text { discharge velocity = } 5 \\
\text { fps, 0.446-in dia. } \\
\text { discharge), SS-316, } \\
\text { dbl mech seal; }\end{array}$ & Reference 3. \\
\hline $\begin{array}{l}\text { H2/Water } \\
\text { Separation Tank }\end{array}$ & $\$ 11,520$ & 4.1 & $\$ 47,347$ & $\begin{array}{l}\text { Assume } 12 \text {-in. } \\
\text { gas/liquid, vane type } \\
\text { separator, } 250 \text { psi } \\
\text { rating; Base cost }= \\
\$ 4800 \text {. Assume } 2.0 \\
\text { multiplier for carbon } \\
\text { steel to stainless, and } \\
1.2 \text { multiplier for } 250 \\
\text { psi rating to } 900 \text { psi } \\
\text { rating. Uninstalled } \\
\text { cost }=\$ 4800 \times 2 \times \\
1.2=\$ 11,520\end{array}$ & Reference 3. \\
\hline $\begin{array}{l}\text { Recycle Water } \\
\text { Pump }\end{array}$ & $\$ 6,400$ & 4.1 & $\$ 26,304$ & $\begin{array}{l}\text { Centrif., horiz., ANSI. } \\
\text { 1-Stage, } 1.0 \text { in dia } \\
\text { disch (min allowed) } \\
\text { ( } 276 \mathrm{~kg} / \mathrm{hr} \text {; assume } \\
\text { discharge velocity = } 5 \\
\text { fps), SS-304, dbl } \\
\text { mechanical seal }\end{array}$ & Reference 3. \\
\hline Regenerator 1 & $\$ 23,500$ & 4.1 & $\$ 96,585$ & $\begin{array}{l}\text { UA=1.35E3Btu/F-hr; } \\
\mathrm{U}=35-70 \text { Btu/hr-ft2-F } \\
\text { (ref. web site-high } \\
\text { press gas to liquid); } \\
\text { Assume } U=35 ; A=\end{array}$ & $\begin{array}{l}\text { Reference } 3 \\
\text { and } 4 .\end{array}$ \\
\hline
\end{tabular}




\begin{tabular}{|c|c|c|c|c|c|}
\hline & & & & $\begin{array}{l}35.87 \text { ft2; Shell/Tube, } \\
\text { Floating Head, small; } \\
35.87 \text { ft2; SS } 304 \text {, } \\
900 \text { psi rating }\end{array}$ & \\
\hline Regenerator 2 & $\$ 18,200$ & 4.1 & $\$ 74,802$ & $\begin{array}{l}\text { UA=7.29E2 Btu/F-hr; } \\
\text { U= 35-70 Btu/hr-ft2-F } \\
\text { (ref. web site); } \\
\text { Assume U = 35; A = } \\
20.83 \mathrm{ft} 2 ; \text { Shell/Tube, } \\
\text { Floating Head, } \\
\text { Medium; } 700 \mathrm{ft} 2 ; \mathrm{SS} \\
304,900 \text { psi rating }\end{array}$ & $\begin{array}{l}\text { Reference } 3 \\
\text { and } 4 .\end{array}$ \\
\hline Regenerator 3 & $\$ 45,800$ & 4.1 & $\$ 188,238$ & $\begin{array}{l}\text { UA=4.56E3 Btu/F-hr; } \\
\text { U= } 35-70 \text { Btu/hr-ft2-F } \\
\text { (ref. web site); } \\
\text { Assume U = 35; A = } \\
130.3 \mathrm{ft} 2 ; \text { Shell/Tube, } \\
\text { Floating Head, } \\
\text { Medium; } 130.3 \mathrm{ft} 2 ; \\
\text { SS } 304,900 \text { psi } \\
\text { rating }\end{array}$ & $\begin{array}{l}\text { Reference } 3 \\
\text { and } 4 .\end{array}$ \\
\hline $\begin{array}{l}\mathrm{H} 2 \mathrm{O} / \mathrm{O} 2 \text { Knockout } \\
\text { Tank }\end{array}$ & $\$ 11,520$ & 4.1 & $\$ 47,347$ & $\begin{array}{l}\text { Assume } 12 \text {-in. } \\
\text { gas/liquid, vane type } \\
\text { separator; Base cost } \\
=\$ 4800 \text {. Assume } \\
2.0 \text { multiplier for } \\
\text { carbon steel to } \\
\text { stainless, and } 1.2 \\
\text { multiplier for } 250 \text { psi } \\
\text { rating to } 900 \text { psi } \\
\text { rating. Uninstalled } \\
\text { cost }=\$ 4800 \times 2 \times \\
1.2=\$ 11,520\end{array}$ & Reference 3. \\
\hline $\begin{array}{l}\text { O2/H2O Separator } \\
\text { Tank }\end{array}$ & $\$ 9,600$ & 4.1 & $\$ 39,456$ & $\begin{array}{l}\text { Assume } 12 \text {-in. } \\
\text { gas/liquid, vane type } \\
\text { separator, } 250 \text { psi } \\
\text { rating; Base cost }= \\
\$ 4800 \text {. Assume } 2.0 \\
\text { multiplier for carbon } \\
\text { steel to stainless. } \\
\text { Uninstalled cost }= \\
\$ 4800 \times 2=\$ 9600\end{array}$ & Reference 3. \\
\hline $\begin{array}{l}\text { O2/Steam } \\
\text { Expander }\end{array}$ & $\$ 104,638$ & 1.8 & $\$ 192,534$ & $\begin{array}{l}\text { Steam turbine, } 84.5 \\
\text { HP, Uninstalled = } \\
\$ 27,000(1998 \$ \text {, } \\
\text { includes condensor } \\
\text { and assessories, Pg } \\
39 \text { of Ref. 5). CECPI } \\
\text { ratio }(1998 / 2010)= \\
539.1 / 389.5= \\
1.3841 . \text { Carbon Steel } \\
\text { to } 304 \text { Stainless Steel } \\
\text { multiplier }=2.8 \text { (Pg. } \\
46 \text { of Ref. } 5) . \\
\text { F(Install) }=1.84\end{array}$ & Reference 5. \\
\hline
\end{tabular}




\begin{tabular}{|c|c|c|c|c|c|}
\hline & & & & $\begin{array}{l}\text { (Page } 74 \text { of Ref. } 5) \\
\text { Uninstalled cost }= \\
\$ 27,000 \times 1.3841 \times \\
2.8=\$ 104,638\end{array}$ & \\
\hline Sweep Water Pump & $\$ 41,700$ & 4.1 & $\$ 171,387$ & $\begin{array}{l}\text { Centrif., horiz., 8- } \\
\text { Stage, Horiz. Split } \\
\text { Case 2-in dia disch } \\
\text { (min dia) (276.2 } \\
\text { kg/hr; assume } \\
\text { discharge velocity = } 5 \\
\text { fps), SS-304, dbl } \\
\text { mechanical seal }\end{array}$ & Reference 3. \\
\hline H2 Recirculator & $\$ 1,500$ & 4.1 & $\$ 6,165$ & $\begin{array}{l}\text { Compressor flowrate } \\
=1.6 \mathrm{cfm}, 15 \mathrm{psi} \\
\text { pressure rise. No } \\
\text { cost data found for } \\
\text { this small turbine. } \\
\text { Assume } \$ 1500 \\
\text { uninstalled cost. }\end{array}$ & $\begin{array}{l}\text { INL } \\
\text { estimate. }\end{array}$ \\
\hline $\begin{array}{l}\text { Natural Gas } \\
\text { Process Heater } 1\end{array}$ & $\$ 59,289$ & 4.1 & $\$ 243,678$ & $\begin{array}{l}\text { Direct Fired Heater, } \\
\text { Cylindrical, } 1000 \text { psi, } \\
2.26 \text { MBTU, SS } 316 ; \\
\text { Uninstalled cost } \\
(1968 \$)=\$ 10,000(1 \\
+0.5+0.15)= \\
\$ 16,500 . \text { CECPI } \\
(2010 / 1968)= \\
539.1 / 150=3.5933 ; \\
\text { Uninstalled cost } \\
(\$ 2010)=\$ 16,500 x \\
3.5933=\$ 59,289\end{array}$ & $\begin{array}{l}\text { Reference 6, } \\
\text { Pg. } 121\end{array}$ \\
\hline $\begin{array}{l}\text { Natural Gas } \\
\text { Process Heater } 2\end{array}$ & $\$ 32,016$ & 4.1 & $\$ 131,586$ & $\begin{array}{l}\text { Direct Fired Heater, } \\
\text { Cylindrical, } 1000 \text { psi, } \\
0.23 \text { MBTU (assume } \\
1 \text { MBTU design), SS } \\
316 ; \text { Uninstalled cost } \\
(1968 \$)=\$ 5,400 \times(1 \\
+0.5+0.15)= \\
\$ 8,910 . \text { CECPI } \\
(2010 / 1968)= \\
539.1 / 150=3.5933 ; \\
\text { Uninstalled cost } \\
(\$ 2010)=\$ 8,910 x \\
3.5933=\$ 32,016\end{array}$ & $\begin{array}{l}\text { Reference 6, } \\
\text { Pg. } 121\end{array}$ \\
\hline $\begin{array}{l}\text { HTE Piping, } \\
\text { Electrical } \\
\text { Equipment } \\
\text { (including AC/DC } \\
\text { conversion), Misc. } \\
\text { HTE plant } \\
\text { Equipment }\end{array}$ & $\$ 121,172$ & 1.2 & $\$ 145,406$ & $\begin{array}{l}\text { Misc. electrical and } \\
\text { piping }=\$ 993,415 x \\
(1.5 / 50)^{\wedge} \cdot 6= \\
\$ 121,172 \text { (cost from } \\
50,000 \mathrm{~kg} / \text { day plant } X \\
\text { ratio of plant sizes). }\end{array}$ & $\begin{array}{l}50,000 \\
\mathrm{~kg} / \text { day plant } \\
\text { analysis }\end{array}$ \\
\hline $\begin{array}{l}\text { Solid Oxide } \\
\text { Electrolyzer (SOE) } \\
\text { Modules }\end{array}$ & $\$ 105,700$ & 1.8 & $\$ 190,260$ & $\begin{array}{l}\text { Uninstalled } \\
\text { Cost }=\$ 50 / \mathrm{kW} \times 2114 \\
\mathrm{~kW}(\mathrm{~F}(\mathrm{INL})=1.8)\end{array}$ & SECA Goal \\
\hline TOTALS & $\$ 669,023$ & & $\$ 1,827,008$ & & \\
\hline
\end{tabular}


The indirect depreciable capital costs are summarized in Table 10. These costs include site preparation, engineering and design work, contingency costs, and one-time licensing and permitting costs. The total calculated indirect depreciable costs in Table 10 is $\$ 244,883$, and when added to the total direct depreciable costs from Table 9, gives total depreciable costs for the reference 1,500 kg/day HTE forecourt plant design of $\$ 2,052,702$.

Table 10. Indirect depreciable capital costs.

\begin{tabular}{|l|r|}
\hline Site Preparation (\$) & $\$ 74,344$ \\
\hline Engineering \& design (\$) & $\$ 30,000$ \\
\hline Process contingency (\$) & $\$ 0$ \\
\hline Project contingency (\$) & $\$ 91,350$ \\
\hline Other (Depreciable) capital (\$) & $\$ 0$ \\
\hline One-time Licensing Fees (\$) & $\$ 0$ \\
\hline Up-Front Permitting Costs (\$) & $\$ 30,000$ \\
\hline Total Indirect Depreciable Capital Costs & $\$ 225,694$ \\
\hline
\end{tabular}

The only potential non-depreciable cost for the reference plant lifecycle analysis would be the cost of land required for the plant site. However, in this forecourt analysis, it is assumed that the land used for locating the hydrogen production and distribution plant is rented, and therefore, is included as part of the cost associated with refueling station operation.

Additional costs to be considered in this HTE hydrogen production plant lifecycle analysis are the operation and maintenance $(\mathrm{O} \& \mathrm{M})$ costs and variable production costs. The operations and maintenance costs include burdened labor and material costs, various plant permits, licenses, fees and taxes. However, for this analysis, it was assumed that the plant is designed for automatic, unattended and continuous operation, so no labor is assumed for the production process. Labor is only assumed for storage and dispensing operations, and is part of the refueling costs discussed later. The resulting fixed O\&M costs (excluding SOE and unplanned replacement costs) are summarized in Table 11.

Table 11. Fixed operating costs.

\begin{tabular}{|l|r|}
\hline Licensing, Permits and Fees (\$/year) & $\$ 1,000.00$ \\
\hline Property tax and insurance rate (\% of total capital investment) & $2 \%$ \\
\hline Property taxes and insurance (\$/year) & $\$ 41,054$ \\
\hline Rent (\$/year) & $\$ 4,186$ \\
\hline Material costs for maintenance and repairs (\$/year) & $\$ 91,350$ \\
\hline Total Fixed Operating Costs & $\$ 137,590$ \\
\hline
\end{tabular}

The total fixed O\&M costs, obtained by summing the costs in Column 2 of the table above, amount to $\$ 137,590$.

In addition to the fixed O\&M costs summarized in Table 11, there are variable production costs to be considered. These variable production costs include energy feedstock and utility costs, and other feedstock costs; all of which can be partially offset by income from any saleable byproduct of the 
hydrogen production process. For the $1,500 \mathrm{~kg} /$ day hydrogen production forecourt plant design, the energy feedstock is the industrial natural gas used by the natural gas-fired heater for process heat, and the energy utility is the required grid industrial electricity used by the electrolysis process and to drive the process system components (pumps, compressors, etc.). Table 13 summarizes the energy feedstock and utility usage per kilogram of hydrogen produced (based on HYSYS analysis), and the resulting variable cost in the startup year (2020) based on H2A default unit energy costs (shown in Column 3 of Table 12.

Table 12. Variable operating energy feedstock and utility requirements and costs in startup year.

\begin{tabular}{|c|c|c|c|c|}
\hline Feedstock & $\begin{array}{c}\text { Lower } \\
\text { Heating } \\
\text { Value } \\
(\mathrm{GJ} / \mathrm{Nm} 3 @ 0 \\
\left.0^{\circ} \mathrm{C}\right)\end{array}$ & $\begin{array}{c}\text { Price in } \\
\text { Startup } \\
\text { Year } \\
(\$ 2010) / \mathrm{Nm} 3 \\
@ 0^{\circ} \mathrm{C}\end{array}$ & $\begin{array}{l}\text { Usage (Nm3 } \\
\left.@ 0^{\circ} \mathrm{C} / \mathrm{kg} \mathrm{H} 2\right)\end{array}$ & $\begin{array}{c}\text { Cost in } \\
\text { Startup Year }\end{array}$ \\
\hline Industrial Natural Gas_metric & 0.036623406 & 0.210137349 & 1.4676 & $\$ 143,858$ \\
\hline & & & & \\
\hline Utility & $\begin{array}{l}\text { Lower } \\
\text { Heating } \\
\text { Value } \\
\text { (GJ/kWh) }\end{array}$ & $\begin{array}{c}\text { Price in } \\
\text { Startup } \\
\text { Year } \\
\text { (\$2010)/kWh }\end{array}$ & $\begin{array}{c}\text { Usage } \\
(\mathrm{kWh} / \mathrm{kg} \mathrm{H} 2)\end{array}$ & $\begin{array}{c}\text { Cost in } \\
\text { Startup Year }\end{array}$ \\
\hline Industrial Electricity_metric & 0.0036 & 0.055420854 & 32.8267 & $\$ 848,641$ \\
\hline
\end{tabular}

The other remaining variable cost is the demineralized water used to replace the water used in the electrolysis process, and to make up for the small amount of water that is not recovered from the hydrogen and oxygen product streams. The amount of demineralized water used per kilogram of hydrogen produced (based on results from HYSYS) is shown in Table 13. Also shown in the table is the amount of oxygen produced per kilogram of hydrogen produced, and the H2A assumed unit values of the demineralized water and oxygen in $2005 \$$. As noted earlier, the demineralized water usage represents a variable cost for the production process, and the oxygen byproduct represents variable income.

Table 13. Other feed and byproduct cost/income.

\begin{tabular}{|c|c|c|}
\hline Feed/utility & $\$(2005) / g a l$ & Usage per kg H2 (gal) \\
\hline Demineralized Water & 0.0049962 & 2.3662 \\
\hline & & \\
\hline Byproduct & $\$(2005) / \mathbf{k g}$ & Production $\mathbf{p e r} \mathbf{~ k g ~ H 2}(\mathbf{k g})$ \\
\hline Oxygen & 0.02 & 7.8449 \\
\hline
\end{tabular}

The resulting total feedstock and utility costs, and byproduct credits in startup year of 2020 are shown in Table 14 for an assumed total yearly hydrogen production rate of $466,470 \mathrm{~kg}$. The total feedstock cost is the yearly cost of the industrial natural gas used for process heat. The total utility cost is the yearly cost of the grid supplied industrial electricity and demineralized water used in the hydrogen production process, and the total byproduct credits represents the income from the yearly production of oxygen. Remaining variable operating costs (e.g. environmental surcharges) were assumed to be $\$ 1,800$, giving total variable operating costs of $\$ 926,626$. 
Table 14. Total feed, utility, and byproduct variable costs for reference forecourt hydrogen production plant.

\begin{tabular}{|l|r|}
\hline Total Feedstock Costs (\$/year) & $\$ 143,858$ \\
\hline Total Utility Costs (\$/year) & $\$ 854,156$ \\
\hline Total Byproduct Credits (\$/year) & $(\$ 73,188)$ \\
\hline $\begin{array}{l}\text { Other variable operating costs (e.g. environmental surcharges) } \\
\text { (\$/year) }\end{array}$ & $\$ 1,800$ \\
\hline Total Variable Operating Costs (\$/year) & $\$ 926,626$ \\
\hline
\end{tabular}

The only remaining operating costs associated with this process are the SOE replacement costs, and other unplanned replacement costs. Because of the relatively simple and compact reference hydrogen production plant design, unplanned replacement costs were assumed to be $2 \%$ of the total depreciable (direct and indirect) capital costs/year, or $\$ 41,054 /$ year in $(2010 \$)$. For the SOE module replacement costs, it was assumed that 1/5 of the SOE cells would be replaced each year (begin in 2021), and that only the cost of the SOE cells $(\$ 50 / \mathrm{kW})$ would be considered, since the remaining module components (vessels, headers, etc.) would not be replaced. The resulting SOE replacement cost would be \$21,140/year (2010\$).

With the above plant operating assumptions and financial information, the H2A spreadsheet performed a lifecycle cost analysis to predict hydrogen production cost and total delivered cost of hydrogen as discussed in the following section.

\subsubsection{Results of lifecycle analysis for reference forecourt design}

The results of the H2A lifecycle cost analysis include a cash flow analysis for the plant construction and startup periods, and for the operating life of the plant. The resulting hydrogen production cost (in 2010 \$) was also determined based on the plant hydrogen-production capacity and assuming an after-tax internal rate of return (IRR) of 10\%. The resulting cost components and total hydrogen production cost along with the total cost of delivered hydrogen are summarized in Table 15.

Table 15. Hydrogen production and delivery cost summary for reference $1500 \mathrm{~kg} / \mathrm{day}$ hydrogen production plant.

\begin{tabular}{|r|r|c|r|}
\hline \multicolumn{5}{|c|}{$\begin{array}{c}\text { Total Cost of } \\
\text { Delivered } \\
\text { Hydrogen }\end{array}$} \\
\hline Cost Component & $\begin{array}{c}\text { Hydrogen Production } \\
\text { Cost Contribution } \\
\mathbf{( \$ / k g )}\end{array}$ & $\begin{array}{c}\text { Compression, } \\
\text { Storage, and } \\
\text { Dispensing Cost } \\
\text { Contribution } \mathbf{( \$ / k g )}\end{array}$ & $\begin{array}{c}\text { Percentage of H2 } \\
\text { Cost }\end{array}$ \\
\hline Capital Costs & $\$ 0.81$ & $\$ 1.18$ & $40.93 \%$ \\
\hline Decommissioning Costs & $\$ 0.01$ & $\$ 0.45$ & $0.16 \%$ \\
\hline Fixed O\&M & $\$ 0.30$ & & $15.45 \%$ \\
\hline Feedstock Costs & $\$ 0.32$ & & $6.61 \%$ \\
\hline Other Raw Material Costs & $\$ 0.00$ & & $-3.22 \%$ \\
\hline $\begin{array}{r}\text { Other Variable Costs } \\
\text { (including utilities) }\end{array}$ & $-\$ 0.16$ & $\$ 0.12$ & $40.07 \%$ \\
\hline Total & $\$ 1.84$ & $\$ 1.75$ & \\
\hline
\end{tabular}


To achieve an after tax internal rate of return of $10 \%$ the required hydrogen price calculated using the $\mathrm{H} 2 \mathrm{~A}$ spreadsheet methodology is $\$ 3.12 / \mathrm{kg}$. This represents the price or cost of the hydrogen leaving the plant gate at $5 \mathrm{MPa}$ pressure. The cost of compression (to 6,250 psia), storage, and dispensing the hydrogen in a co-located refueling station with a convenience store was also calculated using $\mathrm{H} 2 \mathrm{~A}$ default values for refueling station equipment, location, configuration, and operation/delivery scenarios. The resulting calculated total hydrogen delivery cost was $\$ 4.87 / \mathrm{kg}$. The major cost component was capital costs, representing $40.93 \%$ of the total cost of delivered hydrogen ( $26 \%$ of hydrogen production cost). Other variable costs, which primarily consist of the cost of industrial grid electricity used in the hydrogen production process, represent $40.07 \%$ of the delivered cost of hydrogen (59\% of hydrogen production cost). The other remaining major cost components were fixed O\&M and feedstock costs, representing $15.45 \%$ of hydrogen delivered cost (9.6\% of hydrogen production cost) and $6.61 \%$ of hydrogen delivered cost $(10.3 \%$ of hydrogen production cost), respectively. These costs were partially offset by the value of the oxygen byproduct produced in the HTE process, which reduced the hydrogen production costs by $\$ 0.16 / \mathrm{kg}$.

\section{VARIABLE PLANT DESIGN AND OPERATING CONDITONS}

To understand the impact of different plant design configurations and operating conditions on overall plant performance and lifecycle costs, several modifications to the design were made that included replacing the gas fired heaters with electric resistance heaters, changing the operating mode of the electrolyzer, and development of a larger $50,000 \mathrm{~kg} /$ day central hydrogen production plant design. Results of the evaluation of these plant configuration and operating conditions are describes in the following sections of the report.

\subsection{All Electric 1500 kg/day Hydrogen Production Plant}

The HYSYS process model for the all electric $1500 \mathrm{~kg} /$ day hydrogen production plant is shown in Figure 2. The plant was again assumed to be operating in the thermal-neutral mode at $800^{\circ} \mathrm{C}$ and $5 \mathrm{MPa}$. The plant design configuration differs from the reference design in that the natural gas used to provide process heat in the reference design is eliminated, and instead, process heat is provided by industrial electric resistance heaters. Therefore, the plant design in Figure 2 is identical to the reference 1,500 $\mathrm{kg}$ /day plant design discussed in Section 2, except that the Natural Gas Combustor and the two natural gas process heaters (Process HX 1 and Process HX 2) shown in Figure 1were replaced with large industrial electric resistance heaters (Electric Power 1 and Electric Power 2). The remaining components and system configuration shown in Figure 2 are identical to those of the HYSYS model in Figure 1. Since the only difference in the two models is the method of adding heat to the electrolysis and steam sweep input streams, fluid conditions around the loop (shown in Figure 2) are essentially identical to those for the HYSYS model in Figure 1. As expected, the electrolyzer efficiency from Equation (1) above (based on lower heating value of hydrogen) is calculated to be $97.4 \%$, which is virtually the same as that calculated for the reference design in Figure 1 (97.6\%). The small difference is attributed to slight differences in system conditions resulting from the optimization of the two HYSYS models. However, the overall facility hydrogen production efficiency for the all electric plant configuration (from Equation 2 above) is calculated to be $78.1 \%$, compared to $69.5 \%$ for the reference design using natural gas process heaters. The higher overall facility hydrogen production efficiency for the all electric plant configuration in Figure 2, compared to that for the reference design in Figure 1, occurs because a portion of the total natural gas energy input (represented by $m(N G)$ in the denominator of Equation 2) is lost as waste heat (in natural gas streams 4 and 7), that must be rejected to the environment since it cannot be easily recovered by the HTE process. In contrast, there are no equivalent waste heat losses associate with the electric resistance heaters that directly heat the fluid streams. 


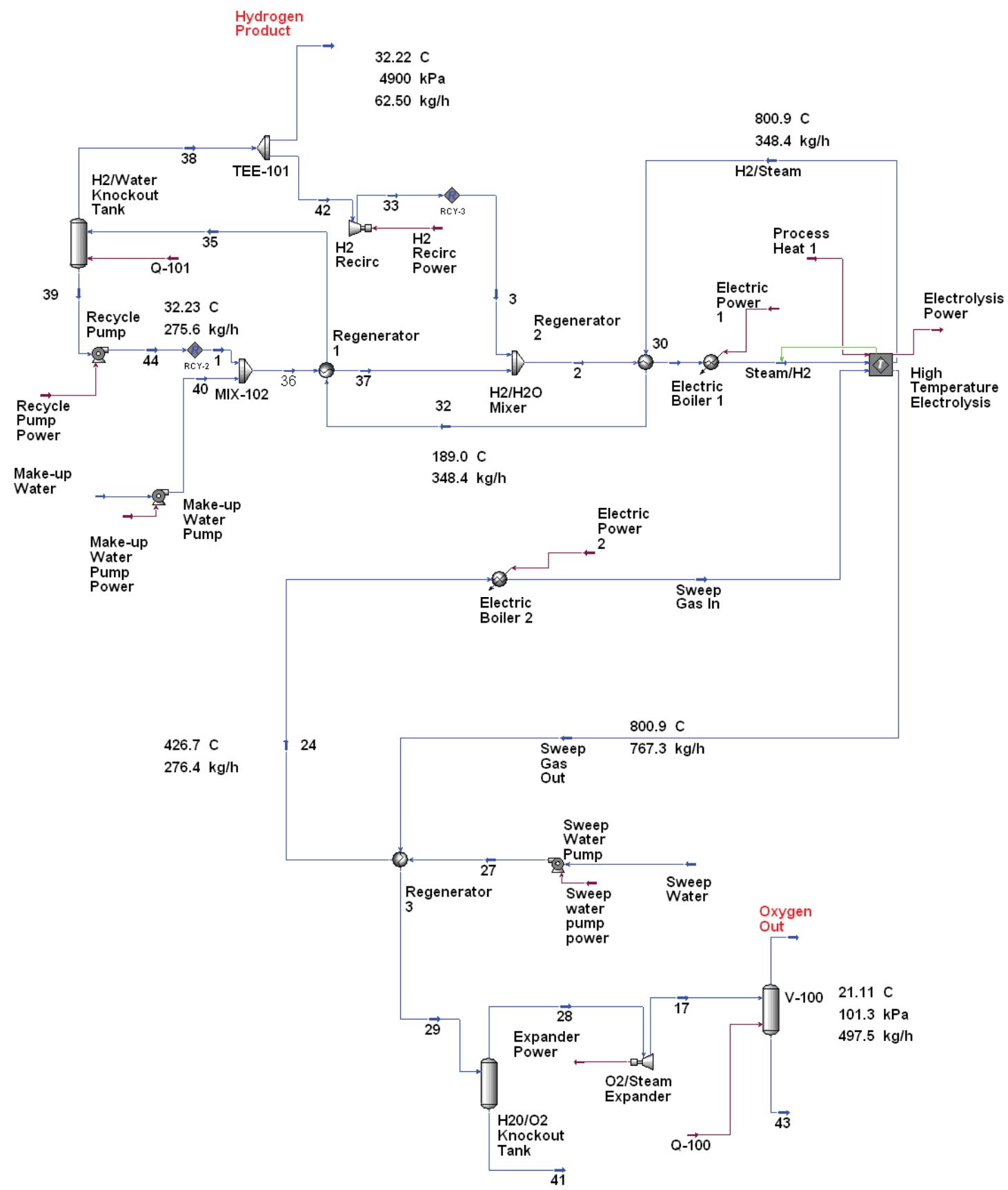

Figure 2. Process flow diagram for all electric $1500 \mathrm{~kg} /$ day hydrogen production plant.

\subsubsection{Economic Analysis of All-Electric 1500 kg/day Hydrogen Production Plant}

An economic analysis of the all-electric $1,500 \mathrm{~kg}$ /day hydrogen production plant was again performed, using the same H2A forecourt spreadsheet used for the reference design. The same base case $\mathrm{H} 2 \mathrm{~A}$ assumptions discussed in Section 2.3.1 and financial assumptions summarized in Table 8 were used in this analysis. The differences in the two economic analyses were therefore related to differences in capital costs associated with the replacement of the natural gas combustor and process heaters in the 
reference design with industrial-size electric resistance heaters in the all-electric design. There were also differences in the energy feed and utility input requirements since the all-electric plant configuration required no industrial natural gas, but utilized more industrial grid electricity for the same hydrogen production rate. As in the economic analysis for the reference plant design; component sizes and operating conditions, feed and utility input requirements, and resulting hydrogen and oxygen production rates for the all-electric hydrogen production plant were based on detailed HYSYS calculated results from the model in Figure 2.

The system and equipment capital cost information for the all-electric hydrogen production plant design is summarized in Table 16. As in the reference plant design, the uninstalled system and equipment costs were obtained from the references provided under "Data Source" in Column 6 of the table, and installed costs in Column 4 were obtain by multiplying the uninstalled costs by the installation factors in Column 3.

Table 16. All electric plant direct depreciable costs.

\begin{tabular}{|c|c|c|c|c|c|}
\hline $\begin{array}{r}\text { Major } \\
\text { pieces/systems } \\
\text { of equipment }\end{array}$ & $\begin{array}{l}\text { Baseline } \\
\text { Uninstalled } \\
\text { Costs }\end{array}$ & $\begin{array}{c}\text { Installation } \\
\text { Cost } \\
\text { Factor }\end{array}$ & $\begin{array}{c}\text { Baseline } \\
\text { Installed } \\
\text { Costs }\end{array}$ & Comments & Data Source \\
\hline $\begin{array}{l}\text { Water Supply } \\
\text { System }\end{array}$ & $\$ 30,368$ & 1.2 & $\$ 36,442$ & $\begin{array}{l}\text { Demineralized water } \\
\text { cost appears as a } \\
\text { feedstock cost in the } \\
\mathrm{H} 2 \mathrm{~A} \text { analysis. } \\
\text { Therefore, this cost is } \\
\text { for the waste water } \\
\text { treatment system } \\
\text { ratioed from } \\
\text { Dominion cost } \\
\text { estimate. Cost }= \\
\$ 500 \mathrm{~K} \times(62.5 \mathrm{~kg} \text { per } \\
\mathrm{hr} / 6660 \mathrm{~kg} \text { per } \\
\mathrm{hr})^{* *} 0.6=\$ 30,368\end{array}$ & Reference 7. \\
\hline $\begin{array}{l}\text { Make-Up Water } \\
\text { Pump }\end{array}$ & $\$ 46,100$ & 4.1 & $\$ 189,471$ & $\begin{array}{l}\text { Centrif., horiz., 8- } \\
\text { Stage, Horiz. Split } \\
\text { Case, } 2.0 \text { in dia disch } \\
\text { (min allowed) (553.2 } \\
\text { kg/hr; assume } \\
\text { discharge velocity = } 5 \\
\text { fps, } 0.446 \text {-in dia. } \\
\text { discharge), SS-316, } \\
\text { dbl mech. seal }\end{array}$ & Reference 3. \\
\hline $\begin{array}{l}\text { H2/Water } \\
\text { Separation Tank }\end{array}$ & $\$ 11,520$ & 4.1 & $\$ 47,347$ & $\begin{array}{l}\text { Assume } 12-\text {-in. } \\
\text { gas/liquid, vane type } \\
\text { separator, } 250 \mathrm{psi} \\
\text { rating; Base cost }= \\
\$ 4800 \text {. Assume } 2.0 \\
\text { multiplier for carbon } \\
\text { steel to stainless, and } \\
1.2 \text { multiplier for } 250 \\
\text { psi rating to } 900 \mathrm{psi} \\
\text { rating. Uninstalled } \\
\text { cost }=\$ 4800 \times 2 \times \\
1.2=\$ 11,520\end{array}$ & Reference 3. \\
\hline
\end{tabular}




\begin{tabular}{|c|c|c|c|c|c|}
\hline $\begin{array}{l}\text { Recycle Water } \\
\text { Pump }\end{array}$ & $\$ 6,400$ & 4.1 & $\$ 26,304$ & $\begin{array}{l}\text { Centrif., horiz., ANSI. } \\
\text { 1-Stage, } 1.0 \text { in dia } \\
\text { disch (min allowed) } \\
\text { ( } 276 \mathrm{~kg} / \mathrm{hr} \text {; assume } \\
\text { discharge velocity = } 5 \\
\text { fps), SS-304, dbl } \\
\text { mech seal; }\end{array}$ & Reference 3. \\
\hline Regenerator 1 & $\$ 45,000$ & 4.1 & $\$ 184,950$ & $\begin{array}{l}\text { UA=4.52E3Btu/F-hr; } \\
\text { U= 35-70 Btu/hr-ft2-F } \\
\text { (ref. web site-high } \\
\text { press gas to liquid); } \\
\text { Assume } U=35 ; A= \\
129.1 \mathrm{ft} 2 \text {; Shell/Tube, } \\
\text { Floating Head, small; } \\
129.1 \mathrm{ft} 2 ; \text { SS } 304 \text {, } \\
900 \text { psi rating }\end{array}$ & $\begin{array}{l}\text { Reference } 3 \\
\text { and } 4 .\end{array}$ \\
\hline Regenerator 2 & $\$ 46,900$ & 4.1 & $\$ 192,759$ & $\begin{array}{l}\mathrm{UA}=4.72 \mathrm{E} 3 \mathrm{Btu} / \mathrm{F}-\mathrm{hr} ; \\
\mathrm{U}=35-70 \mathrm{Btu} / \mathrm{hr}-\mathrm{ft} 2-\mathrm{F} \\
\text { (ref. web site); } \\
\text { Assume } \mathrm{U}=35 ; \mathrm{A}= \\
\text { 134.86 ft2; } \\
\text { Shell/Tube, Floating } \\
\text { Head, Medium; } 700 \\
\mathrm{ft} 2 ; \mathrm{SS} 304,900 \text { psi } \\
\text { rating }\end{array}$ & $\begin{array}{l}\text { Reference } 3 \\
\text { and } 4 .\end{array}$ \\
\hline Regenerator 7 & $\$ 45,900$ & 4.1 & $\$ 188,649$ & $\begin{array}{l}\text { UA=4.57E3 Btu/F-hr; } \\
\text { U= 35-70 Btu/hr-ft2-F } \\
\text { (ref. web site); } \\
\text { Assume } U=35 ; A= \\
\text { 130.6 ft2; Shell/Tube, } \\
\text { Floating Head, } \\
\text { Medium; } 130.6 \mathrm{ft} 2 ; \\
\text { SS } 304,900 \text { psi } \\
\text { rating }\end{array}$ & $\begin{array}{l}\text { Reference } 3 \\
\text { and } 4 .\end{array}$ \\
\hline $\begin{array}{l}\mathrm{H} 2 \mathrm{O} / \mathrm{O} 2 \text { Knockout } \\
\text { Tank }\end{array}$ & $\$ 11,520$ & 4.1 & $\$ 47,347$ & $\begin{array}{l}\text { Assume } 12 \text {-in. } \\
\text { gas/liquid, vane type } \\
\text { separator; Base cost } \\
=\$ 4800 \text {. Assume } \\
2.0 \text { multiplier for } \\
\text { carbon steel to } \\
\text { stainless, and } 1.2 \\
\text { multiplier for } 250 \text { psi } \\
\text { rating to } 900 \text { psi } \\
\text { rating. Uninstalled } \\
\text { cost }=\$ 4800 \times 2 \times \\
1.2=\$ 11,520\end{array}$ & Reference 3. \\
\hline $\begin{array}{l}\text { O2/H2O Separator } \\
\text { Tank }\end{array}$ & $\$ 9,600$ & 4.1 & $\$ 39,456$ & $\begin{array}{l}\text { Assume } 12 \text {-in. } \\
\text { gas/liquid, vane type } \\
\text { separator, } 250 \text { psi } \\
\text { rating; Base cost }= \\
\$ 4800 \text {. Assume } 2.0 \\
\text { multiplier for carbon } \\
\text { steel to stainless. } \\
\text { Uninstalled cost }= \\
\$ 4800 \times 2=\$ 9600\end{array}$ & Reference 3. \\
\hline
\end{tabular}




\begin{tabular}{|c|c|c|c|c|c|}
\hline $\begin{array}{l}\text { O2/Steam } \\
\text { Expander }\end{array}$ & $\$ 104,638$ & 1.8 & $\$ 192,534$ & $\begin{array}{l}\text { Steam turbine, } 84.5 \\
\text { HP, Uninstalled = } \\
\$ 27,000(1998 \$ \text {, } \\
\text { includes condensor } \\
\text { and assessories, } \mathrm{Pg} \\
40 \text { of Ref. 5). CECPI } \\
\text { ratio }(1998 / 2010)= \\
539.1 / 389.5= \\
1.3841 . \text { Carbon Steel } \\
\text { to } 304 \text { Stainless Steel } \\
\text { multiplier }=2.8 \text { (Pg. } \\
46 \text { of Ref. 5). } \\
\text { F(Install) }=1.84 \\
\text { (Page } 74 \text { of Ref. 5). } \\
\text { Uninstalled cost }= \\
27,000 \times 1.3841 \times 2.8 \\
=\$ 104,638\end{array}$ & Reference 5. \\
\hline Sweep Water Pump & $\$ 6,400$ & 4.1 & $\$ 26,304$ & $\begin{array}{l}\text { Centrif., horiz., 8- } \\
\text { Stage, Horiz. Split } \\
\text { Case 2-in dia disch } \\
\text { (min dia) }(276.2 \\
\text { kg/hr; assume } \\
\text { discharge velocity = } 5 \\
\text { fps), SS-304, dbl } \\
\text { mechanical seal }\end{array}$ & Reference 3. \\
\hline H2 Recirculator & $\$ 1,500$ & 4.1 & $\$ 6,165$ & $\begin{array}{l}\text { Compressor flowrate } \\
=1.6 \mathrm{cfm}, 15 \mathrm{psi} \\
\text { pressure rise. No } \\
\text { cost data found for } \\
\text { this small turbine. } \\
\text { Assume } \$ 1500 \\
\text { uninstalled cost. }\end{array}$ & INL estimate. \\
\hline Electric Boiler 1 & $\$ 39,971$ & 4.1 & $\$ 164,281$ & $\begin{array}{l}\text { Electric Resistance } \\
\text { Heaters: } \\
\text { - } \$ 77,000 / \mathrm{MW}(2008 \\
\$) \times 0.5191 \mathrm{MW}= \\
\$ 39,971\end{array}$ & Reference 9. \\
\hline Electric Boiler 2 & $\$ 5,159$ & 4.1 & $\$ 21,203$ & $\begin{array}{l}\text { Electric Resistance } \\
\text { Heaters: } \\
\sim \$ 77,000 / \mathrm{MW}(2008 \\
\$) \times 0.067 \mathrm{MW}= \\
\$ 5,159\end{array}$ & Reference 9. \\
\hline $\begin{array}{l}\text { HTE Piping, } \\
\text { Electrical } \\
\text { Equipment } \\
\text { (including AC/DC } \\
\text { conversion), Misc. } \\
\text { HTE plant } \\
\text { Equipment }\end{array}$ & $\$ 121,172$ & 1.2 & $\$ 145,406$ & $\begin{array}{l}\text { Misc. electrical and } \\
\text { piping }=\$ 993,415 \mathrm{x} \\
(1.5 / 50)^{\wedge} \cdot 6= \\
\$ 121,172 \text { (cost from } \\
2008 \mathrm{H} 2 \mathrm{~A} \text { analysis } \mathrm{X} \\
\text { ratio of plant sizes). }\end{array}$ & Reference 8. \\
\hline $\begin{array}{l}\text { Solid Oxide } \\
\text { Electrolyzer (SOE) } \\
\text { Modules }\end{array}$ & $\$ 105,800$ & 1.8 & $\$ 190,440$ & $\begin{array}{l}\text { Uninstalled } \\
\text { Cost }=\$ 50 / \mathrm{kW} \times 2116 \\
\mathrm{~kW}(\mathrm{~F}(\mathrm{INL})=1.8)\end{array}$ & $\begin{array}{l}\text { INL/Ceramete } \\
\text { c Estimate; } \\
\text { SECA cost } \\
\text { goal }\end{array}$ \\
\hline TOTALS & $\$ 637,948$ & & $\$ 1,699,059$ & & \\
\hline
\end{tabular}


For the all-electric plant configuration, the total installed cost of plant equipment (total depreciable direct capital investment) obtained by summing the costs in Column 4 of Table 13 is $\$ 1,699,059$. This compares with capital costs of $\$ 1,827,008$ for the reference hydrogen production plant design. Although the industrial-size electric resistance heater used to provide process heat for the all-electric plant design are relatively expensive, the total installed equipment cost for the all-electric plant configuration is still slightly lower than that for the reference design because of the relative complexity of the combined natural gas combustor and process heaters used in the reference design.

The total indirect depreciable capital cost for the all-electric design is also slightly lower than that for the reference design $(\$ 219,297$ versus $\$ 225,694$ from Table 10) because project contingency costs were assumed to be $5 \%$ of total direct depreciable costs.

The total fixed operation and maintenance cost for the all-electric design is also slightly lower than that for the reference design $(\$ 128,506$ versus $\$ 137,590$ from Table 11) because property tax and insurance, and material for maintenance and repair costs which are a part of the total fixed operating and maintenance costs were assumed to be $2 \%$ and $5 \%$ of total direct depreciable costs, respectively.

Although total depreciable capital costs (direct and indirect) and total fixed operation and maintenance costs were lower for the all-electric design compared to the reference design, the variable operating costs have the biggest impact on the lifecycle cost comparisons for the two designs. This is because the reference design uses lower cost natural gas to supply process heat, requiring less total grid electricity than does the all-electric plant design. Comparisons of the total utility and feed usage and costs for the two designs are shown in Table 17.

Table 17. Comparison of feed and utility costs for reference and all-electric hydrogen plant designs.

\begin{tabular}{|c|c|c|c|c|}
\hline Utility/Feed & $\begin{array}{l}\text { Reference } \\
\text { Design Usage }\end{array}$ & $\begin{array}{l}\text { All-Electric } \\
\text { Design Usage }\end{array}$ & $\begin{array}{l}\text { Reference Design } \\
\text { Cost }\end{array}$ & $\begin{array}{l}\text { All-Electric } \\
\text { Design Cost }\end{array}$ \\
\hline Demineralized Water & $\begin{array}{c}2.4 \\
\mathrm{gal} / \mathrm{kg} \mathrm{H} 2\end{array}$ & $\begin{array}{c}2.4 \\
\mathrm{gal} / \mathrm{kg} \mathrm{H} 2\end{array}$ & $\$ 5,515 / \mathrm{yr}$. & $\$ 5,529 / \mathrm{yr}$. \\
\hline $\begin{array}{l}\text { Feedstock (Natural } \\
\text { Gas) }\end{array}$ & $\begin{array}{c}1.47 \\
\mathrm{Nm} 3 / \mathrm{kg} \mathrm{H} 2\end{array}$ & -- & $\$ 143,858 / y r$. & $\$ 0$ \\
\hline Utility (Electricity) & $\begin{array}{c}32.8 \\
\mathrm{kWh} / \mathrm{kg} \mathrm{H} 2\end{array}$ & $\begin{array}{c}42.256 \\
\mathrm{kWh} / \mathrm{kg}\end{array}$ & $\$ 848,641 / \mathrm{yr}$. & $\$ 1,092,409 / \mathrm{yr}$. \\
\hline $\begin{array}{l}\text { Other variable } \\
\text { operating costs (e.g. } \\
\text { environmental } \\
\text { surcharges) }\end{array}$ & -- & -- & $\$ 1,800 / \mathrm{yr}$. & $\$ 1,800 / \mathrm{yr}$. \\
\hline Oxygen byproduct & $\begin{array}{c}7.85 \\
\mathrm{~kg} / \mathrm{kg} \mathrm{H} 2\end{array}$ & $\begin{array}{c}7.77 \\
\mathrm{~kg} / \mathrm{kg} \mathrm{H} 2\end{array}$ & $(\$ 73,188 / y r)$. & $(\$ 72,450 / \mathrm{yr})$. \\
\hline $\begin{array}{l}\text { Total variable } \\
\text { operating cost }\end{array}$ & & & $\$ 926,626 / y r$. & $\$ 1,027,288$ \\
\hline
\end{tabular}

The results summarized in Table 17 clearly show that although there are no natural gas costs associated with the all-electric hydrogen production plant, the increased electricity usage associate with 
the all-electric design results in yearly electric costs that exceed the savings in natural gas costs. As a result, the total yearly utility and feed variable costs are higher for the all-electric hydrogen production plant than the reference hydrogen production plant $(\$ 1,027,288$ versus $\$ 926,626)$. Since the remaining variable costs in the all-electric design, including SOEC replacement costs and other unplanned replacement costs, were assumed to be the same as those for the reference plant design, total operating costs for the all-electric design will also be higher than for the reference plant design.

Results of the lifecycle cost analysis for the all-electric hydrogen plant design are summarized in Table 18, which shows the cost breakdown along with the total hydrogen production cost and the total cost of delivered hydrogen. The hydrogen production cost for the all-electric plant design is $\$ 3.26 / \mathrm{kg}$ of hydrogen produced compared with a cost of $\$ 3.12 / \mathrm{kg}$ for the reference $1,500 \mathrm{~kg} /$ day hydrogen production plant (Table 15). The delivered cost of hydrogen for the all-electric plant design is also higher at $\$ 5.01 / \mathrm{kg}$ compared with $\$ 4.87 / \mathrm{kg}$ for the reference design (Table 15). These differences in cost are attributable to the increased usage and resulting higher total cost for electricity for the all-electric hydrogen production plant, which more than offsets the slightly lower capital costs and the eliminated natural gas feedstock costs, when compared to the reference $1,500 \mathrm{~kg}$ /day plant costs.

Table 18. Hydrogen production and delivery cost summary for all-electric $1500 \mathrm{~kg} /$ day hydrogen production plant.

\begin{tabular}{|r|r|r|r|}
\hline \multicolumn{2}{|c|}{ Specific Item Cost Calculation } & \multicolumn{2}{c|}{$\begin{array}{c}\text { Total Cost of } \\
\text { Delivered Hydrogen }\end{array}$} \\
\hline Cost Component & $\begin{array}{c}\text { Compression, } \\
\text { Hydrogen Production } \\
\text { Cost Contribution } \mathbf{( \$ \mathbf { k g } )}\end{array}$ & $\begin{array}{c}\text { Storage, and } \\
\text { Dispensing Cost } \\
\text { Contribution (\$/kg) }\end{array}$ & $\begin{array}{c}\text { Percentage of H2 } \\
\text { Cost }\end{array}$ \\
\hline Capital Costs & $\$ 0.77$ & $\$ 1.18$ & $38.95 \%$ \\
\hline Decommissioning Costs & $\$ 0.01$ & $\$ 0.45$ & $0.15 \%$ \\
\hline Fixed O\&M & $\$ 0.28$ & & $0.00 \%$ \\
\hline Other Raw Material Costs & $\$ 0.00$ & & $-3.10 \%$ \\
\hline Byproduct Credits & $\$ 0.00$ & $\$ 0.12$ & $49.38 \%$ \\
\hline Tother Variable Costs (including & $-\$ 0.16$ & $\$ 1.75$ & \\
\hline
\end{tabular}

\subsection{Reference 1500 kg/day Hydrogen Production Plant Operating below the Thermal-Neutral Voltage}

For the $1,500 \mathrm{~kg} /$ day reference hydrogen production plant design with steam sweep described in Section 2, the electrolyzer was operated in the thermal-neutral mode where the ohmic heating associated with the electrolyte ionic resistance equaled the endothermic cooling of the steam reduction process. This resulted in an $800^{\circ} \mathrm{C}$ constant temperature adiabatic process that eliminated the need for heating or cooling of the electrolyzer. In the present case, the electrolyzer was operated below thermal-neutral in order to reduce the required electrical power to the electrolyzer and increase its overall efficiency (based on the lower heating value of hydrogen). This results in the endothermic cooling of the steam reduction process exceeding the ohmic heating associate with the various stack loss mechanisms. In order to maintain the electrolyzer operating temperature at $800^{\circ} \mathrm{C}$, the steam sweep gas can be used as a heat transfer fluid in a manner that is analogous to the typical situation in the solid oxide fuel cell mode of operation where excess air is used as a cooling gas. So, to maintain the stack operating temperature in 
the SOEC mode, the inlet steam sweep temperature was increased to $900^{\circ} \mathrm{C}$ and the inlet steam flow rate was increase until the desired $800^{\circ} \mathrm{C}$ electrolysis outlet operating temperature was achieved. Other than changing the electrolyzer operating mode and the steam sweep flow rate and temperature, the overall system configuration and operating conditions for the HTE process loop remained identical to those for the reference plant design described in Section 2.

The HYSYS process model for the 1,500 kg/day hydrogen production plant operating below thermalneutral is shown in Figure 3. The plant configuration for this model is identical to the reference plant process model described in Section 2.1. Again, fluid conditions around the process loops (temperature, pressure and mass flow rate) are included on the process flow diagram. A comparison of fluid conditions for the hydrogen process loop (upper portion of Figure 3) shows that conditions for these streams are virtually identical to those for the reference plant design. However, temperature and mass flow rates in the steam sweep loop in the lower right portion of the Figure 3 are considerably higher than those for the reference plant design in Figure 2. As discussed earlier, these higher steam sweep temperatures and flow rates were necessary to provide the added heat to maintain the electrolysis outlet operating temperature at $800^{\circ} \mathrm{C}$ while operating the electrolysis modules below thermal-neutral. This change in electrolyzer operating mode also required an increase in the natural gas and air feed to the Natural Gas Combustor since a larger mass flow of steam is heated to a higher temperature in the steam sweep process heat exchanger (Process HX 2). In addition, since more excess steam exited the electrolyzer with the oxygen byproduct, flow rates and conditions in the in the oxygen byproduct portion of the steam sweep loop downstream of the electrolyzer were also changed.

For convenience, Table 19 shows selected comparisons of conditions in the hydrogen process loop, steam sweep loop, and combustion loop. These comparisons show that conditions in the hydrogen loop remained essentially the same as those for the reference design, even though conditions changed significantly in the steam sweep and combustion gas loops to accommodate operation of the electrolysis stack at below thermal-neutral conditions.

The results in Table 19 show that the steam sweep flow had to increase by about a factor of 20 to provide the required heat for the electrolysis process when operating below the thermal-neutral voltage. To supply this heat, the natural gas mass flow to the combustor was increased by approximately a factor of 5. All of this additional heat was delivered to the steam sweep gas through the Process HX 2 heat exchanger, whose heat duty increased by a factor of nearly 50 . Since the hydrogen process loop conditions were not changed, the heat duty for the Process HX 1 heat exchanger remained essentially the same for operation of the hydrogen production plant at and below thermal-neutral.

As expected, when the electrolyzer operating mode moved from thermal-neutral to below thermalneutral, the electrolyzer efficiency (as defined in Equation 1) increased from $97.6 \%$ to $119.4 \%$ (based on the lower heating value of hydrogen). However, because of the increased electrolyzer process heat 


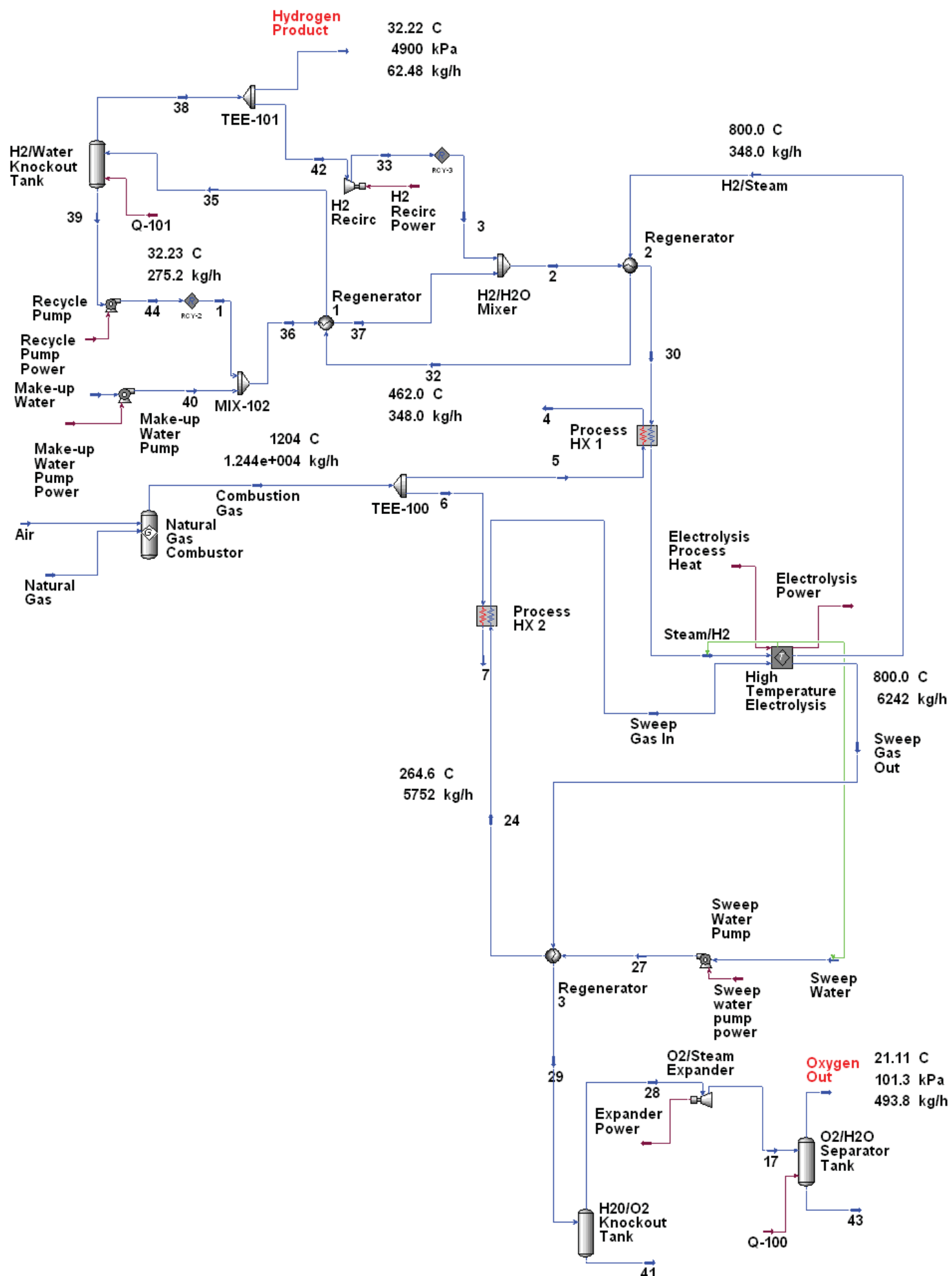

Figure 3. Process flow diagram for reference $1500 \mathrm{~kg} /$ day hydrogen production plant operating below thermalneutral. 
requirement and resulting increase in natural gas feed to the combustion heater, the overall facility hydrogen production efficiency (as defined in Equation 2) decreased from $78.8 \%$ to $33.1 \%$ (based on the lower heating value of hydrogen). The combination of the reduced overall facility hydrogen production efficiency combined with the increased cost of equipment to handle the increased steam sweep and combustion gas flows, resulted in increased hydrogen production costs for operation of the hydrogen production plant below the thermal-neutral voltage, as described in the next section.

Table 19. Comparison of selected hydrogen production loop conditions for operation at and below thermal-neutral.

\begin{tabular}{|c|c|c|}
\hline Loop conditions & $\begin{array}{l}\text { Hydrogen production plant } \\
\text { operating in thermal-neutral } \\
\text { mode }\end{array}$ & $\begin{array}{l}\text { Reference hydrogen } \\
\text { production plant operating } \\
\text { below thermal-neutral }\end{array}$ \\
\hline \multicolumn{3}{|l|}{ Hydrogen Process Loop } \\
\hline $\begin{array}{l}\text { Temperature of Steam } / \mathrm{H} 2 \text { into } \\
\text { electrolyzer, }{ }^{\circ} \mathrm{C}\end{array}$ & 800 & 800 \\
\hline $\begin{array}{l}\text { Mass flow of Steam } / \mathrm{H} 2 \text { into } \\
\text { electrolyzer, } \mathrm{kg} / \mathrm{hr}\end{array}$ & 838.3 & 838.3 \\
\hline $\begin{array}{l}\text { Temperature of H2/Steam out of } \\
\text { electrolyzer, }{ }^{\circ} \mathrm{C}\end{array}$ & 799.1 & 800 \\
\hline $\begin{array}{l}\text { Mass flow of } \mathrm{H} 2 / \text { Steam out of } \\
\text { electrolyzer, } \mathrm{kg} / \mathrm{hr}\end{array}$ & 348.1 & 348 \\
\hline $\begin{array}{l}\text { Mass flow of Hydrogen Product } \\
\text { stream, } \mathrm{kg} / \mathrm{hr}\end{array}$ & 62.5 & 62.5 \\
\hline \multicolumn{3}{|l|}{ Steam Sweep Loop } \\
\hline $\begin{array}{l}\text { Temperature of Sweep Gas In } \\
\text { (electrolyzer), }{ }^{\circ} \mathrm{C}\end{array}$ & 800 & 900 \\
\hline $\begin{array}{l}\text { Mass flow of Sweep Gas In } \\
\text { (electrolizer), }{ }^{\circ} \mathrm{C}\end{array}$ & 276.2 & 5752 \\
\hline $\begin{array}{l}\text { Temperature of Sweep Gas Out } \\
\text { (electrlolizer), }{ }^{\circ} \mathrm{C}\end{array}$ & 799.1 & 800 \\
\hline $\begin{array}{l}\text { Mass flow of Sweep Gas Out } \\
\text { (electrolyzer), }{ }^{\circ} \mathrm{C}\end{array}$ & 766.9 & 6242 \\
\hline $\begin{array}{l}\text { Percent of Oxygen in Sweep Gas } \\
\text { Out (electrolyzer), }{ }^{\circ} \mathrm{C}\end{array}$ & $50 \%$ & $4.6 \%$ \\
\hline \multicolumn{3}{|l|}{ Natural Gas/Combustion Loop } \\
\hline $\begin{array}{l}\text { Natural Gas mass flow (feed to } \\
\text { Combustor), } \mathrm{kg} / \mathrm{hr}\end{array}$ & 65.9 & 352.4 \\
\hline Process HX 1 heat duty, $\mathrm{kJ} / \mathrm{hr}$ & $2.385 \mathrm{E} 6$ & $2.383 \mathrm{E} 6$ \\
\hline Process HX 2 heat duty, $\mathrm{kJ} / \mathrm{hr}$ & $2.431 \mathrm{E} 5$ & $1.16 \mathrm{E} 7$ \\
\hline
\end{tabular}




\subsubsection{Economic Analysis of the Reference $1500 \mathrm{~kg} / \mathrm{day}$ Hydrogen Production Plant Operating below Thermal-Neutral Voltage}

As in the previous cases described earlier, an economic analysis of the reference $1,500 \mathrm{~kg} / \mathrm{day}$ hydrogen production plant operating below the thermal-neutral voltage was performed using the $\mathrm{H} 2 \mathrm{~A}$ spreadsheet for a forecourt plant design to calculate both hydrogen production and distribution costs. The same base case H2A assumptions discussed in Section 2.3.1 and financial assumptions summarized in Table 8 were used in this analysis. The differences in the two economic analyses were therefore related to differences in capital costs associated with the larger steam sweep flows and associated larger equipment costs, along with differences in the energy feed and utility input requirements; since operating the reference plant below thermal-neutral reduced the demand for grid electricity to power the electrolysis modules, but significantly increased the demand for natural gas to provide process heat to the steam sweep system. As in the previous economic analyses; component sizes and operating conditions, feed and utility input requirements, and resulting hydrogen and oxygen production rates for the reference hydrogen production plant operating below the thermal-neutral voltage were based on detailed HYSYS calculated results from the model in Figure 3.

The system and equipment capital cost information for the reference hydrogen production plant design operating below the thermal-neutral voltage is summarized in Table 20. As in previous cases, the uninstalled system and equipment costs were obtained from the references provided under "Data Source" in Column 6 of the table, and installed costs in Column 4 were obtain by multiplying the uninstalled costs by the installation factors in Column 3.

Table 20. Reference $1500 \mathrm{~kg} /$ day plant operating below thermal-neutral.

\begin{tabular}{|c|c|c|c|c|c|}
\hline $\begin{array}{r}\text { Major } \\
\text { pieces/systems } \\
\text { of equipment }\end{array}$ & $\begin{array}{c}\text { Baseline } \\
\text { Uninstalled } \\
\text { Costs }\end{array}$ & $\begin{array}{c}\text { Installation } \\
\text { Cost } \\
\text { Factor }\end{array}$ & $\begin{array}{c}\text { Baseline } \\
\text { Installed } \\
\text { Costs }\end{array}$ & Comments & Data Source \\
\hline $\begin{array}{l}\text { Water Treatment } \\
\text { System }\end{array}$ & $\$ 30,368$ & 1.2 & $\$ 36,442$ & $\begin{array}{l}\text { The cost of } \\
\text { demineralized water } \\
\text { appears as a } \\
\text { feedstock cost in the } \\
\mathrm{H} 2 \mathrm{~A} \text { analysis. } \\
\text { Therefore, this cost } \\
\text { is for the waste } \\
\text { water treatment } \\
\text { system ratioed from } \\
\text { Dominion cost } \\
\text { estimate. Cost = } \\
\$ 500 \mathrm{~K} \times(62.5 \mathrm{~kg} \\
\text { per hr/6660 kg per } \\
\mathrm{hr})^{\star *} 0.6=\$ 30,368\end{array}$ & Reference 7. \\
\hline $\begin{array}{l}\text { Make-Up Water } \\
\text { Pump }\end{array}$ & $\$ 46,100$ & 4.1 & $\$ 189,471$ & $\begin{array}{l}\text { Centrif., horiz., 8- } \\
\text { Stage, Horiz. Split } \\
\text { Case, } 2.0 \text { in dia } \\
\text { disch (min allowed) } \\
\text { ( } 553.2 \mathrm{~kg} / \mathrm{hr} ; \\
\text { assume discharge } \\
\text { velocity } 5 \mathrm{fps}, \\
0.446-\text {-in dia. } \\
\text { discharge), SS-316, } \\
\text { dbl mech. seal; }\end{array}$ & Reference 3. \\
\hline
\end{tabular}




\begin{tabular}{|c|c|c|c|c|c|}
\hline $\begin{array}{l}\text { H2/Water } \\
\text { Separation Tank }\end{array}$ & $\$ 11,520$ & 4.1 & $\$ 47,347$ & $\begin{array}{l}\text { Assume } 12 \text {-in. } \\
\text { gas/liquid, vane type } \\
\text { separator, } 250 \text { psi } \\
\text { rating; Base cost }= \\
\$ 4800 \text {. Assume } 2.0 \\
\text { multiplier for carbon } \\
\text { steel to stainless, } \\
\text { and } 1.2 \text { multiplier for } \\
250 \text { psi rating to } 900 \\
\text { psi rating. } \\
\text { Uninstalled cost = } \\
\$ 4800 \times 2 \times 1.2= \\
\$ 11,520\end{array}$ & Reference 3 \\
\hline $\begin{array}{l}\text { Recycle Water } \\
\text { Pump }\end{array}$ & $\$ 6,400$ & 4.1 & $\$ 26,304$ & $\begin{array}{l}\text { Centrif., horiz., } \\
\text { ANSI. 1-Stage, } 1.0 \\
\text { in dia disch (min } \\
\text { allowed) }(276 \mathrm{~kg} / \mathrm{hr} \text {; } \\
\text { assume discharge } \\
\text { velocity }=5 \mathrm{fps}) \text {, SS- } \\
304, \mathrm{dbl} \text { mech. seal }\end{array}$ & Reference 3 \\
\hline Regenerator 1 & $\$ 23,500$ & 4.1 & $\$ 96,585$ & $\begin{array}{l}\mathrm{UA}=1.35 \mathrm{E} 3 \mathrm{Btu} / \mathrm{F}-\mathrm{hr} \\
\mathrm{U}=35-70 \mathrm{Btu} / \mathrm{hr} \text {-ft2- } \\
\mathrm{F} \text { (ref. web site-high } \\
\text { press gas to liquid); } \\
\text { Assume } \mathrm{U}=35 ; \mathrm{A}= \\
35.87 \mathrm{ft} 2 ; \\
\text { Shell/Tube, Floating } \\
\text { Head, small; } 35.87 \\
\text { ft2; SS } 304,900 \text { psi } \\
\text { rating }\end{array}$ & $\begin{array}{l}\text { Reference } 3 \\
\text { and } 4 .\end{array}$ \\
\hline Regenerator 2 & $\$ 18,200$ & 4.1 & $\$ 74,802$ & $\begin{array}{l}\text { UA=7.29E2 Btu/F- } \\
\text { hr; U= 35-70 Btu/hr- } \\
\text { ft2-F (ref. web site); } \\
\text { Assume U = 35; A = } \\
20.83 \mathrm{ft} 2 ; \\
\text { Shell/Tube, Floating } \\
\text { Head, Medium; } 700 \\
\text { ft2; SS 304, } 900 \text { psi } \\
\text { rating }\end{array}$ & $\begin{array}{l}\text { Reference } 3 \\
\text { and } 4 .\end{array}$ \\
\hline Regenerator 3 & $\$ 276,600$ & 4.1 & $\$ 1,136,826$ & $\begin{array}{l}\text { UA=6.09E4 Btu/F- } \\
\text { hr; U= 35-70 Btu/hr- } \\
\text { ft2-F (ref. web site); } \\
\text { Assume U = 35; A = } \\
1740 \mathrm{ft} 2 ; \text { Shell/Tube, } \\
\text { Floating Head, } \\
\text { Medium; } 130.3 \mathrm{ft} 2 ; \\
\text { SS } 304,900 \mathrm{psi} \\
\text { rating }\end{array}$ & $\begin{array}{l}\text { Reference } 3 \\
\text { and } 4 .\end{array}$ \\
\hline $\begin{array}{l}\mathrm{H} 2 \mathrm{O} / \mathrm{O} 2 \text { Knockout } \\
\text { Tank }\end{array}$ & $\$ 11,520$ & 4.1 & $\$ 47,347$ & $\begin{array}{l}\text { Assume } 12 \text {-in. } \\
\text { gas/liquid, vane type } \\
\text { separator; Base cost } \\
=\$ 4800 \text {. Assume } \\
2.0 \text { multiplier for } \\
\text { carbon steel to } \\
\text { stainless, and } 1.2 \\
\text { multiplier for } 250 \text { psi }\end{array}$ & Reference 3 \\
\hline
\end{tabular}




\begin{tabular}{|c|c|c|c|c|c|}
\hline & & & & $\begin{array}{l}\text { rating to } 900 \mathrm{psi} \\
\text { rating. Uninstalled } \\
\text { cost }=\$ 4800 \times 2 \times \\
1.2=\$ 11,520\end{array}$ & \\
\hline $\begin{array}{l}\text { O2/H2O Separator } \\
\text { Tank }\end{array}$ & $\$ 9,600$ & 4.1 & $\$ 39,456$ & $\begin{array}{l}\text { Assume 12-in. } \\
\text { gas/liquid, vane type } \\
\text { separator, } 250 \text { psi } \\
\text { rating; Base cost = } \\
\$ 4800 \text {. Assume } 2.0 \\
\text { multiplier for carbon } \\
\text { steel to stainless. } \\
\text { Uninstalled cost = } \\
\$ 4800 \times 2=\$ 9600\end{array}$ & Reference 3. \\
\hline $\begin{array}{l}\text { O2/Steam } \\
\text { Expander }\end{array}$ & $\$ 147,268$ & 2.9 & $\$ 425,605$ & $\begin{array}{l}\text { Steam turbine, } 540 \\
\text { HP, Uninstalled = } \\
\$ 38,000(1998 \$, \\
\text { includes condensor } \\
\text { and assessories, Pg } \\
40 \text { of Ref. 5). } \\
\text { CECPI ratio } \\
(1998 / 2010)= \\
539.1 / 389.5= \\
1.3841 . \text { Carbon } \\
\text { Steel to } 304 \\
\text { Stainless Steel } \\
\text { multiplier = 2.8 (Pg. } \\
46 \text { of Ref. 5); F } \\
\text { (Install) }=2.89 \\
\text { (Page } 74 \text { of Ref. 5). } \\
\text { Uninstalled cost = } \\
38,000 \times 1.3841 \times \\
2.8=\$ 147,268\end{array}$ & Reference 5. \\
\hline Sweep Water Pump & $\$ 46,100$ & 4.1 & $\$ 189,471$ & $\begin{array}{l}\text { Centrif., horiz., 8- } \\
\text { Stage, Horiz. Split } \\
\text { Case 2-in dia disch } \\
\text { (min dia) (5752 } \\
\text { kg/hr; assume } \\
\text { discharge velocity = } \\
5 \text { fps; disch dia = } \\
1.44 \text { in.), SS-304, } \\
\text { dbl mech seal }\end{array}$ & Reference 3. \\
\hline H2 Recirculator & $\$ 1,500$ & 4.1 & $\$ 6,165$ & $\begin{array}{l}\text { Compressor flowrate } \\
=1.6 \mathrm{cfm}, 15 \mathrm{psi} \\
\text { pressure rise. No } \\
\text { cost data found for } \\
\text { this small turbine. } \\
\text { Assume } \$ 1500 \\
\text { uninstalled cost. }\end{array}$ & INL estimate. \\
\hline $\begin{array}{l}\text { Natural Gas } \\
\text { Process Heater } 1\end{array}$ & $\$ 59,289$ & 4.1 & $\$ 243,678$ & $\begin{array}{l}\text { Direct Fired Heater, } \\
\text { Cylindrical, } 1000 \text { psi, } \\
2.26 \text { MBTU, SS 316; } \\
\text { F= 4.74; Uninstalled } \\
\text { cost }(1968 \$)= \\
\$ 10,000(1+0.5+ \\
0.15)=\$ 16,500 . \\
\text { CECPI }(2010 / 1968)\end{array}$ & $\begin{array}{l}\text { Reference 6, } \\
\text { Pg. } 121\end{array}$ \\
\hline
\end{tabular}




\begin{tabular}{|c|c|c|c|c|c|}
\hline & & & & $\begin{array}{l}=539.1 / 150= \\
3.5933 ; \text { Uninstalled } \\
\text { cost }(\$ 2010)= \\
\$ 16,500 \times 3.5933= \\
\$ 59,289\end{array}$ & \\
\hline $\begin{array}{l}\text { Natural Gas } \\
\text { Process Heater } 2\end{array}$ & $\$ 207,515$ & 4.1 & $\$ 852,887$ & $\begin{array}{l}\text { Direct Fired Heater, } \\
\text { Cylindrical, } 1000 \text { psi, } \\
11 \text { MBTU, SS } 316 ; \\
\text { F= 4.11; Uninstalled } \\
\text { cost }(1968 \$)= \\
\$ 35,000(1+0.5+ \\
0.15)=\$ 57,750 . \\
\text { CECPI }(2010 / 1968) \\
=539.1 / 150= \\
3.5933 ; \text { Uninstalled } \\
\text { cost }(\$ 2010)= \\
\$ 57,750 \times 3.5933= \\
\$ 207,515\end{array}$ & $\begin{array}{l}\text { Reference 6, } \\
\text { Pg. } 121\end{array}$ \\
\hline $\begin{array}{l}\text { HTE Piping, } \\
\text { Electrical } \\
\text { Equipment } \\
\text { (including AC/DC } \\
\text { conversion), Misc. } \\
\text { HTE plant } \\
\text { Equipment }\end{array}$ & $\$ 121,172$ & 1.2 & $\$ 145,406$ & $\begin{array}{l}\text { Misc. electrical and } \\
\text { piping }=\$ 993,415 x \\
(1.5 / 50)^{\wedge} .6= \\
\$ 121,172 \text { (cost from } \\
2008 \mathrm{H} 2 \mathrm{~A} \text { analysis } \\
\mathrm{X} \text { ratio of plant } \\
\text { sizes). }\end{array}$ & Reference 8. \\
\hline $\begin{array}{l}\text { Solid Oxide } \\
\text { Electrolyzer (SOE) } \\
\text { Modules }\end{array}$ & $\$ 86,300$ & 1.8 & $\$ 155,340$ & $\begin{array}{l}\text { Uninstalled } \\
\text { Cost }=\$ 50 / \mathrm{kW} x \\
1726 \mathrm{~kW} \\
(\mathrm{~F}(\mathrm{INL})=1.8)\end{array}$ & $\begin{array}{l}\text { INL/Cerametec } \\
\text { Estimate; } \\
\text { SECA cost goal }\end{array}$ \\
\hline TOTALS & $\$ 1,102,952$ & & $\$ 3,713,131$ & & \\
\hline
\end{tabular}

For the reference hydrogen production plant operating below the thermal-neutral voltage, the total installed cost of plant equipment (total depreciable direct capital investment) obtained by summing the costs in Column 4 of Table 20 is $\$ 3,713,131$. This is nearly twice the installed equipment capital cost of $\$ 1,827,008$ for the reference hydrogen production plant design operating in the thermal-neutral mode. The primary reason for the increase in equipment costs when operating below thermal-neutral is the larger equipment costs associated with the steam sweep and natural gas process heating systems needed for heating the electrolyzer modules.

The total indirect depreciable capital cost for the reference plant design operating below thermalneutral is also higher than that for the reference design ( $\$ 320,001$ versus $\$ 225,694$ from Table 10) because project contingency costs were assumed to be $5 \%$ of total direct depreciable costs.

The total fixed operation and maintenance cost for the reference plant design operating below thermal-neutral is also higher than that for the reference design $(\$ 271,505$ versus $\$ 137,590$ from Table 11) because property tax and insurance, and material for maintenance and repair costs which are a part of the total fixed operating and maintenance costs were assumed to be $2 \%$ and $5 \%$ of total direct depreciable costs, respectively.

In addition to the higher total depreciable capital costs (direct and indirect) and total fixed operation and maintenance costs when operating the hydrogen production plant below thermal-neutral, variable operating costs are also higher because of the added process heat requirements. However, the higher process heat requirements are partially offset by the lower grid electrical power requirements of the 
electrolyzer modules when operating the electrolyzer below thermal-neutral. Comparisons of the total utility and feed usage and costs for the two designs are shown in Table 21.

Table 21. Comparison of feed and utility costs for reference hydrogen production plant operating at and below thermalneutral.

\begin{tabular}{|c|c|c|c|c|}
\hline Utility/Feed & $\begin{array}{l}\text { Reference } \\
\text { Thermal- } \\
\text { Neutral } \\
\text { Design Usage }\end{array}$ & $\begin{array}{l}\text { Reference } \\
\text { Below Thermal- } \\
\text { Neutral Design } \\
\text { Usage }\end{array}$ & $\begin{array}{l}\text { Reference } \\
\text { Thermal-Neutral } \\
\text { Design Cost } \\
\text { (startup year) }\end{array}$ & $\begin{array}{l}\text { Reference Below } \\
\text { Thermal-Neutral } \\
\text { Design Cost } \\
\text { (startup year) }\end{array}$ \\
\hline Demineralized Water & $\begin{array}{c}2.4 \\
\mathrm{gal} / \mathrm{kg} \mathrm{H} 2\end{array}$ & $\begin{array}{c}2.4 \\
\mathrm{gal} / \mathrm{kg} \mathrm{H} 2\end{array}$ & $\$ 5,515 / \mathrm{yr}$ & $\$ 5,490 / \mathrm{yr}$ \\
\hline $\begin{array}{l}\text { Feedstock (Natural } \\
\text { Gas) }\end{array}$ & $\begin{array}{c}1.47 \\
\mathrm{Nm} 3 / \mathrm{kg} \mathrm{H} 2\end{array}$ & $\begin{array}{c}7.86 \\
\mathrm{Nm} 3 / \mathrm{kg} \mathrm{H} 2\end{array}$ & $\$ 143,858 / y r$ & $\$ 770,155 / \mathrm{yr}$. \\
\hline Utility (Electricity) & $\begin{array}{c}32.8 \\
\mathrm{kWh} / \mathrm{kg} \mathrm{H} 2\end{array}$ & $\begin{array}{c}21.4 \\
\mathrm{kWh} / \mathrm{kg}\end{array}$ & $\$ 848,641 / \mathrm{yr}$ & $\$ 552,378 / \mathrm{yr}$ \\
\hline $\begin{array}{l}\text { Other variable } \\
\text { operating costs (e.g. } \\
\text { environmental } \\
\text { surcharges) }\end{array}$ & -- & -- & $\$ 1,800 / \mathrm{yr}$. & $\$ 1,800 / \mathrm{yr}$. \\
\hline Oxygen byproduct & $\begin{array}{c}7.85 \\
\mathrm{~kg} / \mathrm{kg} \mathrm{H} 2\end{array}$ & $\begin{array}{c}7.77 \\
\mathrm{~kg} / \mathrm{kg} \mathrm{H} 2\end{array}$ & $(\$ 73,188 / y r)$. & (\$71,934/yr.) \\
\hline $\begin{array}{l}\text { Total variable } \\
\text { operating cost }\end{array}$ & & & $\$ 926,626 / y r$. & $\$ 1,257,889 / \mathrm{yr}$. \\
\hline
\end{tabular}

The results summarized in Table 21 clearly show that although there is a reduction in electrical costs to power the electrolysis process, this is more than offset by the increased demand for natural gas to meet the process heat requirements when operating below the thermal-neutral voltage. As a result, the total yearly utility and feed variable costs are about $36 \%$ higher for the reference hydrogen production plant operating below thermal-neutral than for operation in the thermal-neutral mode $(\$ 1,257,889 / \mathrm{yr}$ versus $\$ 926,626 / y r)$. Since the remaining costs for the two electrolysis operating modes, including SOE replacement costs and other unplanned replacement costs(at $2 \%$ of direct capital costs), were assumed to be the same, total costs for the hydrogen production plant operating below the thermal-neutral voltage will also be higher than for operation at the thermal-neutral voltage.

Results of the lifecycle cost analysis for the reference hydrogen production plant operating below the thermal neutral voltage are summarized in Table 22, which shows the cost breakdown along with the total hydrogen production cost and the total cost of delivered hydrogen. The hydrogen production cost for operation below thermal-neutral is $\$ 4.89 / \mathrm{kg}$ of hydrogen produced compared with a cost of $\$ 3.12 / \mathrm{kg}$ for the reference $1,500 \mathrm{~kg} /$ day hydrogen production plant operating in the thermal-neutral mode (Table 15). The delivered cost of hydrogen for operation below thermal-neutral is also higher at $\$ 6.64 / \mathrm{kg}$ compared with $\$ 4.87 / \mathrm{kg}$ for operation in the thermal-neutral mode (Table 15). These differences in cost are attributable to the increased equipment capital costs associated with the increased steam sweep temperature and mass flow, and the higher feedstock (natural gas) cost to accommodate the increased 
process heat demand. However, the increased natural gas costs are partially offset by the reduced cost of electricity to power the electrolysis process when operating below thermal-neutral.

Table 22 . Hydrogen production and delivery cost summary for all-electric $1500 \mathrm{~kg} / \mathrm{day}$ reference hydrogen production plant operating below thermal-neutral.

\begin{tabular}{|c|c|c|c|}
\hline \multicolumn{2}{|l|}{ Specific Item Cost Calculation } & \multirow{2}{*}{$\begin{array}{l}\text { Total Cost of } \\
\text { Delivered Hydrogen } \\
\text { Compression, } \\
\text { Storage, and } \\
\text { Dispensing Cost } \\
\text { Contribution }(\$ / \mathrm{kg})\end{array}$} & $\$ 6.64$ \\
\hline Cost Component & $\begin{array}{l}\text { Hydrogen Production } \\
\text { Cost Contribution }(\$ / \mathbf{k g})\end{array}$ & & $\begin{array}{l}\text { Percentage of } \mathrm{H} 2 \\
\text { Cost }\end{array}$ \\
\hline Capital Costs & $\$ 1.51$ & $\$ 1.18$ & $40.60 \%$ \\
\hline Decommissioning Costs & $\$ 0.02$ & & $0.23 \%$ \\
\hline Fixed O\&M & $\$ 0.59$ & $\$ 0.45$ & $15.72 \%$ \\
\hline Feedstock Costs & $\$ 1.72$ & & $25.95 \%$ \\
\hline Other Raw Material Costs & $\$ 0.00$ & & $0.00 \%$ \\
\hline Byproduct Credits & $-\$ 0.15$ & & $-2.32 \%$ \\
\hline $\begin{array}{r}\text { Other Variable Costs (including } \\
\text { utilities) }\end{array}$ & $\$ 1.20$ & $\$ 0.12$ & $19.82 \%$ \\
\hline Total & $\$ 4.89$ & $\$ 1.75$ & \\
\hline
\end{tabular}

\subsection{Large 50,000 kg/day Central Hydrogen Production Plant}

The HYSYS flow diagram for a large central HTE hydrogen production plant capable of producing $50,000 \mathrm{~kg} /$ day of hydrogen is shown in Figure 4. The process model flow configuration is identical to the reference 1,500 kg/day forecourt plant design described in Section 2.1, except that system flows and power levels were increased to produce the required $50,000 \mathrm{~kg} /$ day $(2,095 \mathrm{~kg} / \mathrm{hr})$ of hydrogen. Figure 4 also shows fluid conditions (temperature, pressure and mass flow rate) at various points around the system. As noted earlier, the electrolyzer was operated in the thermal-neutral mode. A total of 350,000 electrolysis cells with a cell area of $225 \mathrm{~cm}^{2}$, current density of $0.6999 \mathrm{amps} / \mathrm{cm}^{2}$, and area specific resistance of $0.2776 \mathrm{ohms}-\mathrm{cm}^{2}$ was required to achieve the desired hydrogen production rate for an electrolysis operating temperature of $800^{\circ} \mathrm{C}$. From Equation (1), the resulting calculated electrolyzer efficiency (based on the lower heating value of hydrogen) was calculated to be $97.5 \%$, and the overall facility hydrogen production efficiency from Equation (2) was calculated to be $69.4 \%$.

As noted earlier, the relatively high overall system hydrogen production efficiency was in part achieved because the O2/Steam Expander produced more power than was required to drive the other components in the process and steam sweep loops. As a result, the power recovered with the steam expander contributed about $3 \%$ of the electric power required for the electrolysis process, resulting in a fractional reduction in the electric power supplied from the grid.

The detailed plant design and performance information obtained from the HYSYS model in Figure 4 was used in the H2A lifecycle cost analysis described in the following section.

\subsubsection{Economic Analysis of Large 50,000 kg/day Central Hydrogen Production Plant}

An economic analysis of the large $50,000 \mathrm{~kg}$ /day hydrogen production plant design operating in the thermal-neutral mode was performed using the H2A spreadsheet for a central plant design to calculate overall lifecycle costs. The H2A central plant spreadsheet model is essentially the same as the forecourt spreadsheet model, except that the central plant model performs carbon sequestration calculations, whereas the forecourt plant model performs refueling station compression, storage, and dispensing 
calculations. As noted earlier, the detailed plant performance and process information input to the H2A spreadsheet was obtained from the HYSYS model shown in Figure 4.

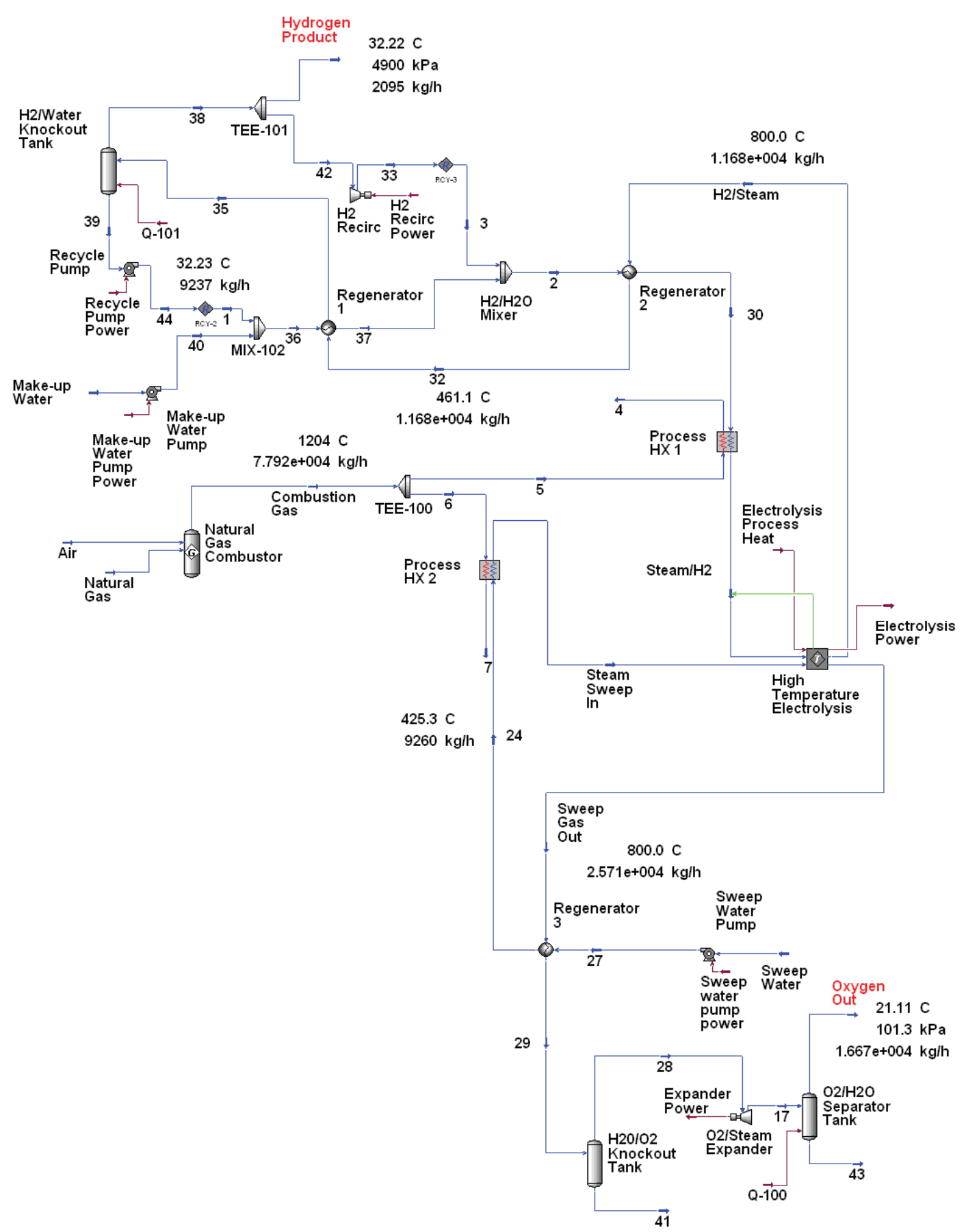

Figure 4. Process flow diagram for reference $50,000 \mathrm{~kg} / \mathrm{day}$ hydrogen production plant.

The financial information used in the spreadsheet was primarily based on the assumptions described in Section 2.3.1 for a central plant design, but in this case, the assumed plant capacity factor was 95\% based on the relatively simple design and assumed reliability of the SOE modules. Plant-specific financial input included information on the construction time, plant startup date, plant design production 
capacity, capital expenditure rate during construction, and revenue and operating costs during startup. Table 23 shows selected financial input values used in the analysis of the 50,000 kg/day HTE central plant design. Most of the financial input uses the recommended guidelines of the H2A methodology discussed in Section 2.3.1 for a central plant design. The start-up date is 2020 with an assumed 2 year construction period.

Plant capital cost information input by the user includes uninstalled and installed system and equipment costs, indirect depreciable capital costs (including site preparation, engineering and design, licensing and permitting, and associated contingencies), and non-depreciable capital costs (primarily the cost of the land for the plant site).

Table 23. Basic financial assumptions for HTE central plant design.

\begin{tabular}{|c|c|}
\hline Reference year & 2010 \\
\hline Assumed start-up year & 2020 \\
\hline Length of Construction Period (years) & 2 \\
\hline$\%$ of Capital Spent in 1st Year of Construction & $60 \%$ \\
\hline$\%$ of Capital Spent in 2nd Year of Construction & $40 \%$ \\
\hline \% of Capital Spent in 3rd Year of Construction & $0 \%$ \\
\hline$\%$ of Capital Spent in 4th Year of Construction & $0 \%$ \\
\hline Start-up Time (years) & $\overline{1}$ \\
\hline Plant life (years) & 40 \\
\hline Analysis period (years) & 40 \\
\hline Depreciation Schedule Length (years) & 7 \\
\hline Depreciation Type & MACRS \\
\hline \% Equity Financing & $100 \%$ \\
\hline Interest rate on debt, if applicable (\%) & $3.50 \%$ \\
\hline Debt period (years) & 40 \\
\hline$\%$ of Fixed Operating Costs During Start-up (\%) & $100 \%$ \\
\hline$\%$ of Revenues During Start-up (\%) & $75 \%$ \\
\hline$\%$ of Variable Operating Costs During Start-up (\%) & $75 \%$ \\
\hline Decommissioning costs (\% of depreciable capital investment) & $10 \%$ \\
\hline Salvage value (\% of total capital investment) & $10 \%$ \\
\hline Inflation rate $(\%)$ & $1.9 \%$ \\
\hline After-tax Real IRR (\%) & $10.0 \%$ \\
\hline State Taxes (\%) & $6.0 \%$ \\
\hline Federal Taxes (\%) & $35.0 \%$ \\
\hline Total Tax Rate (\%) & $38.90 \%$ \\
\hline WORKING CAPITAL (\% of yearly change in operating costs) & $15 \%$ \\
\hline
\end{tabular}


The system and equipment capital cost information for the $50,000 \mathrm{~kg} /$ day central hydrogen production plan is summarized in Table 24. Uninstalled system and equipment costs were obtained from the references provided under "Data Source" in Column 6 of the table. For the most part, an installation factor of 4.11 was used to calculate installed equipment costs (Column 4) except as noted. For example, the installation cost factor for the Solid Oxide Electrolyzer (SOE) modules was assumed to be 1.8 since it is expected that the future design of these modules will be relatively simple and compact, allowing easy turnkey installation of multiple modules without significant installation costs. In effect, the 1.8 multiplier represents the cost of the completely assembled SOE module brought to the sight and installed in a plugin fashion at minimal cost. The total installed cost of plant equipment obtained by summing the costs in Column 4 is $\$ 18,683,570$. This represents the total depreciable direct capital investment.

Table 24. Large central plant direct depreciable capital costs.

\begin{tabular}{|c|c|c|c|c|c|}
\hline $\begin{array}{r}\text { Major } \\
\text { pieces/systems } \\
\text { of equipment }\end{array}$ & $\begin{array}{c}\text { Baseline } \\
\text { Uninstalled } \\
\text { Costs }\end{array}$ & $\begin{array}{c}\text { Installation } \\
\text { Cost } \\
\text { Factor }\end{array}$ & $\begin{array}{c}\text { Baseline } \\
\text { Installed } \\
\text { Costs }\end{array}$ & Comments & Data Source \\
\hline $\begin{array}{l}\text { Water Supply } \\
\text { System }\end{array}$ & $\$ 249,802$ & 1.20 & $\$ 299,762$ & $\begin{array}{l}\text { The cost of } \\
\text { demineralized water } \\
\text { appears as a } \\
\text { feedstock cost in the } \\
\mathrm{H} 2 \mathrm{~A} \text { analysis. } \\
\text { Therefore, this cost } \\
\text { is for the waste } \\
\text { water treatment } \\
\text { system ratioed from } \\
\text { Dominion cost } \\
\text { estimate. Cost }= \\
\$ 500 \mathrm{~K} \times(2095 \mathrm{~kg} \\
\text { per } \mathrm{hr} / 6660 \mathrm{~kg} \mathrm{per} \\
\mathrm{hr})^{\star \star} 0.6=\$ 249802\end{array}$ & Reference 7 \\
\hline $\begin{array}{l}\text { Make-Up Water } \\
\text { Pump }\end{array}$ & $\$ 60,100$ & 4.11 & $\$ 247,011$ & $\begin{array}{l}\text { Centrif., horiz., 8- } \\
\text { Stage, Horiz. Split } \\
\text { Case, } 2.6 \text { in dia } \\
\text { disch (4.089e4 Ib/hr; } \\
\text { assume discharge } \\
\text { velocity = } 5 \mathrm{fps}, 2.6- \\
\text { in dia. discharge), } \\
\text { SS-316, dbl mech } \\
\text { seal }\end{array}$ & Reference 3. \\
\hline $\begin{array}{l}\text { H2/Water } \\
\text { Separation Tank }\end{array}$ & $\$ 67,950$ & 4.11 & $\$ 279,275$ & $\begin{array}{l}\text { Assume } 30 \text {-in. wet, } \\
\text { ceramic lined } \\
\text { separator, } \\
\text { atmospheric } \\
\text { pressure; Base cost } \\
=\$ 45,300 \text {. Assume } \\
1.5 \text { multiplier for } \\
\text { atmospheric } \\
\text { pressure to } 900 \text { psi } \\
\text { rating. Uninstalled } \\
\text { cost }=\$ 45,300 \times 1.5 \\
=\$ 67,950\end{array}$ & Reference 3. \\
\hline
\end{tabular}




\begin{tabular}{|c|c|c|c|c|c|}
\hline $\begin{array}{l}\text { Recycle Water } \\
\text { Pump }\end{array}$ & $\$ 8,900$ & 4.11 & $\$ 36,579$ & $\begin{array}{l}\text { Centrif., horiz., ANSI. } \\
\text { 1-Stage, } 1.82 \text { in dia } \\
\text { disch ( } 9237 \mathrm{~kg} / \mathrm{s} \text {; } \\
\text { assume discharge } \\
\text { velocity = } 5 \mathrm{fps} \text { ), SS- } \\
304, \text { dbl mech seal }\end{array}$ & Reference 3. \\
\hline Regenerator 1 & $\$ 217,600$ & 4.11 & $\$ 894,336$ & $\begin{array}{l}\mathrm{UA}=4.53 \mathrm{E} 4 \mathrm{Btu} / \mathrm{F}-\mathrm{hr} ; \\
\mathrm{U}=35-70 \mathrm{Btu} / \mathrm{hr} \text {-ft2- } \\
\mathrm{F} \text { (ref. web site-high } \\
\text { press gas to liquid); } \\
\text { Assume } \mathrm{U}=35 ; \mathrm{A}= \\
1294 \mathrm{ft} 2 ; \text { Shell/Tube, } \\
\text { Floating Head, large; } \\
1294 \mathrm{ft} 2 ; \text { SS } 304 \text {, } \\
900 \text { psi rating }\end{array}$ & Reference 3 \\
\hline Regenerator 2 & $\$ 143,600$ & 4.11 & $\$ 590,196$ & $\begin{array}{l}\text { UA=2.45E4 Btu/F-hr; } \\
U=35-70 \text { Btu/hr-ft2- } \\
\text { F (ref. web site); } \\
\text { Assume U = 35; A = } \\
700 \text { ft2; Shell/Tube, } \\
\text { Floating Head, } \\
\text { Medium; } 700 \text { ft2; SS } \\
304,900 \text { psi rating }\end{array}$ & Reference 3. \\
\hline Regenerator 3 & $\$ 583,200$ & 4.11 & $\$ 2,396,952$ & $\begin{array}{l}\text { UA=1.53E5 Btu/F-hr; } \\
U=35-70 \text { Btu/hr-ft2- } \\
\text { F (ref. web site); } \\
\text { Assume U = 35; A = } \\
4371 \mathrm{ft} 2 ; \text { Shell/Tube, } \\
\text { Floating Head, } \\
\text { Medium; } 4371 \mathrm{ft} 2 ; \\
\text { SS } 304,900 \mathrm{psi} \\
\text { rating }\end{array}$ & Reference 3 \\
\hline $\begin{array}{l}\mathrm{H} 2 \mathrm{O} / \mathrm{O} 2 \text { Knockout } \\
\text { Tank }\end{array}$ & $\$ 67,950$ & 4.11 & $\$ 279,275$ & $\begin{array}{l}\text { Assume } 30 \text {-in. wet, } \\
\text { ceramic lined } \\
\text { separator, } \\
\text { atmospheric } \\
\text { pressure; Base cost } \\
=\$ 45,300 \text {. Assume } \\
1.5 \text { multiplier for } \\
\text { atmospheric } \\
\text { pressure to } 900 \mathrm{psi} \\
\text { rating. Uninstalled } \\
\text { cost }=\$ 45,300 \times 1.5 \\
=\$ 67,950\end{array}$ & Reference 3. \\
\hline $\begin{array}{l}\mathrm{O} 2 / \mathrm{H} 2 \mathrm{O} \text { Separator } \\
\text { Tank }\end{array}$ & $\$ 45,300$ & 4.11 & $\$ 186,183$ & $\begin{array}{l}\text { Assume } 30 \text {-in. wet, } \\
\text { ceramic lined } \\
\text { separator, } \\
\text { atmospheric } \\
\text { pressure; Base cost } \\
=\$ 45,300 .\end{array}$ & Reference 3. \\
\hline
\end{tabular}




\begin{tabular}{|c|c|c|c|c|c|}
\hline $\begin{array}{l}\text { O2/Steam } \\
\text { Expander }\end{array}$ & $\$ 813,850$ & 1.35 & $\$ 1,098,698$ & $\begin{array}{l}\text { Steam turbine, } 2,113 \\
\text { HP, Uninstalled }= \\
\$ 210,000(1998 \$ \text {, } \\
\text { includes condensor } \\
\text { and assessories, Pg } \\
40 \text { of Ref. 5). CECPI } \\
\text { ratio }(1998 / 2010)= \\
539.1 / 389.5= \\
\text { 1.3841. Carbon } \\
\text { Steel to } 304 \\
\text { Stainless Steel } \\
\text { multiplier }=2.8 \text { (Pg. } \\
46 \text { of Ref. 5). } \\
\text { F(Install) }=1.35 \\
\text { (Page } 74 \text { of Ref. } 5) \text {. } \\
\text { Uninstalled cost }= \\
\$ 210,000,000 x \\
1.3841 \times 2.8= \\
\$ 813,850\end{array}$ & Reference 5. \\
\hline $\begin{array}{l}\text { Sweep Water } \\
\text { Pump }\end{array}$ & $\$ 41,700$ & 4.11 & $\$ 171,387$ & $\begin{array}{l}\text { Centrif., horiz., ANSI. } \\
\text { 8-Stage, split case } \\
1.82 \text { in (min allowed } \\
\text { dia = } 2.0 \mathrm{in}) \mathrm{dia} \\
\text { disch }(9260 \mathrm{~kg} / \mathrm{s} ; \\
\text { assume discharge } \\
\text { velocity = } 5 \mathrm{fps}), \text { SS- } \\
304, \mathrm{dbl} \text { mech seal }\end{array}$ & Reference 3. \\
\hline H2 Recirculator & $\$ 12,298$ & 4.11 & $\$ 50,545$ & $\begin{array}{l}\text { Compressor flowrate } \\
=3,130 \mathrm{cfm}, 15 \mathrm{psi} \\
\text { pressure rise. No } \\
\text { cost data found for } \\
\text { this small turbine. } \\
\text { Ratio from } 1500 \\
\mathrm{~kg} / \text { day plant. } \$ 1500 \\
\mathrm{x}(50 / 1.5)^{\star *} 0.6= \\
\$ 12,298 \text { uninstalled } \\
\text { cost. }\end{array}$ & INL estimate \\
\hline $\begin{array}{l}\text { Natural Gas-Fired } \\
\text { Process Heater } 1\end{array}$ & $\$ 948,631$ & 4.11 & $\$ 3,898,873$ & $\begin{array}{l}\text { Direct Fired Heater, } \\
\text { Cylindrical, } 1000 \text { psi, } \\
75.74 \text { MBTU, SS } \\
316 ; \text { F }=4.11 ; \\
\text { Uninstalled cost } \\
(1968 \$)=\$ 160,000 \\
(1+0.5+0.15)= \\
\$ 264,000 . \text { CECPI } \\
(2010 / 1968)= \\
539.1 / 150=3.5933 ; \\
\text { Uninstalled cost } \\
(\$ 2010)=\$ 264000 x \\
3.5933=\$ 948,631\end{array}$ & $\begin{array}{l}\text { Reference 6, } \\
\text { Pg. } 121\end{array}$ \\
\hline
\end{tabular}




\begin{tabular}{|c|c|c|c|c|c|}
\hline $\begin{array}{l}\text { Natural Gas-Fired } \\
\text { Process Heater } 2\end{array}$ & $\$ 166,010$ & 4.11 & $\$ 682,301$ & $\begin{array}{l}\text { Direct Fired Heater, } \\
\text { Cylindrical, } 1000 \text { psi, } \\
7.69 \mathrm{MBTU}, \mathrm{SS} 316 ; \\
\mathrm{F}=4.11 ; \text { Uninstalled } \\
\text { cost }(1968 \$)= \\
\$ 28,000(1+0.5+ \\
0.15)=\$ 46,200 . \\
\text { CECPI }(2010 / 1968) \\
=539.1 / 150= \\
3.5933 ; \text { Uninstalled } \\
\text { cost }(\$ 2010)= \\
\$ 46,200 \times 3.5933= \\
\$ 166,010\end{array}$ & $\begin{array}{l}\text { Reference 6, } \\
\text { Pg. } 121\end{array}$ \\
\hline $\begin{array}{l}\text { HTE Piping, } \\
\text { Electrical } \\
\text { Equipment } \\
\text { (including AC/DC } \\
\text { conversion), Misc. } \\
\text { HTE plant } \\
\text { Equipment }\end{array}$ & $\$ 993,415$ & 1.20 & $\$ 1,192,098$ & $\begin{array}{l}\text { Misc. electrical and } \\
\text { piping }=\$ 5,750,00 \mathrm{x} \\
50 / 300=\$ 958,333 \\
\text { (cost from } 2008 \mathrm{H} 2 \mathrm{~A} \\
\text { analysis } \mathrm{X} \text { ratio of } \\
\text { plant sizes). } \\
\text { Transformer/Rectifier } \\
\text { Unit }=\$ 35,082 ; \text { total } \\
\text { uninstalled = } \\
\$ 993,415\end{array}$ & $\begin{array}{l}\text { Transf/Rect } \\
\text { Unit cost and } \\
\text { installation } \\
\text { factor from } \\
\text { Ramsden } \\
\text { (Reference 1). } \\
\text { H2A } \\
\text { Electrolysis } \\
\text { Central Plant } \\
50,000 \text { kg/day } \\
\text { analysis. } \\
\text { Other misc. } \\
\text { mechanical } \\
\text { and electrical } \\
\text { ratioed from } \\
\text { Reference } 8 .\end{array}$ \\
\hline $\begin{array}{l}\text { Solid Oxide } \\
\text { Electrolyzer (SOE) } \\
\text { Modules }\end{array}$ & $\$ 3,544,500$ & 1.80 & $\$ 6,380,100$ & $\begin{array}{l}\text { Uninstalled } \\
\text { Cost }=\$ 50 / \mathrm{kW} x \\
7.089 \mathrm{E} 4 \mathrm{~kW}= \\
(\mathrm{F}(\mathrm{INL})=1.8\end{array}$ & $\begin{array}{l}\text { INL/Cerametec } \\
\text { Estimate; } \\
\text { SECA goal }\end{array}$ \\
\hline TOTALS & $\$ 7,964,806$ & & $\$ 18,683,570$ & & \\
\hline
\end{tabular}

In addition to the above direct depreciable capital costs for the hydrogen production plant, the H2A central plant spreadsheet also calculates the capital cost for carbon sequestration (pipeline, injection wells, compressors, etc.) using a standard set of analysis assumptions, and information obtained from HYSYS on the amount of carbon dioxide $\left(\mathrm{CO}_{2}\right)$ produced by the natural gas combustion process shown in Figure 4. The calculated total direct capital costs for carbon sequestration for the large central hydrogen production plant producing $50,000 \mathrm{~kg} /$ day of hydrogen was $\$ 32,690,093$.

Indirect depreciable capital costs for the large central hydrogen production plant are summarized in Table 25. These costs include site preparation, engineering and design work, contingency costs, and upfront permitting costs. As indicated in the table, these costs were either estimated or assumed to be a percentage of the total direct depreciable hydrogen plant costs. The total calculated indirect depreciable costs in Table 25 is $\$ 7,636,593$, and when added to the total hydrogen plant direct depreciable costs from Table $24(\$ 18,683,570)$ gives total depreciable costs without carbon sequestration of $\$ 26,320,163$. If total direct capital costs for carbon sequestration $(\$ 32,690,093)$, are added to the plant depreciable costs, the total depreciable costs for the $50,000 \mathrm{~kg}$ /day HTE central plant design with carbon sequestration is $\$ 59,010,256$. 
Table 25. Large central plant Indirect depreciable costs.

\begin{tabular}{|l|l|}
\hline Site Preparation (\$), $1 \%$ of direct capital costs & $\$ 186,836$ \\
\hline Engineering \& design $(\$), 8 \%$ of direct capital costs & $\$ 1,494,686$ \\
\hline Project contingency (\$), 30\% of direct capital costs & $\$ 5,605,071$ \\
\hline Up-Front Permitting Costs (\$), Estimated & $\$ 350,000$ \\
\hline Total Indirect Depreciable Capital Costs & $\$ 7,636,593$ \\
\hline
\end{tabular}

The only non-depreciable cost for the large central hydrogen production plant was the cost of land required for the plant site. In this case, it was assumed that 5 acres of land would be required at a cost of $\$ 5,000$ / acre, for a total non-depreciable cost of $\$ 25,000$. When this cost was added to the depreciable costs, the total capital cost for the large central hydrogen production plant was $\$ 59,035,256$.

Additional costs to be considered in this large central hydrogen production plant lifecycle analysis are the fixed and variable yearly operating costs. The fixed operating costs include burdened labor, taxes and insurance and material costs for maintenance and repairs. These costs are summarized in Table 26.

Table 26. Fixed operating costs for large central hydrogen production plant.

\begin{tabular}{|l|r|}
\hline Total plant staff (number of FTEs employed by plant) & 10 \\
\hline Burdened labor cost, including overhead (\$/man-hr) & $\$ 50.00$ \\
\hline Labor cost, \$/year & $\$ 1,040,000$ \\
\hline G\&A rate (\% of labor cost) & $20 \%$ \\
\hline G\&A (\$/year) & $\$ 208,000$ \\
\hline Licensing, Permits and Fees (\$/year) & $\$ 0.00$ \\
\hline Property tax and insurance rate (\% of total capital investment) & $2 \%$ \\
\hline Property taxes and insurance (\$/year) & $\$ 1,180,705$ \\
\hline Material costs for maintenance and repairs (\$/year) & $\$ 3,750,000$ \\
\hline Total Fixed Operating Costs & $\$ 6,178,705$ \\
\hline
\end{tabular}

The total fixed operating costs, shown at the bottom of the second column in Table 26, amount to $\$ 6,178.705$

In addition to the fixed operating costs summarized in Table 26, there are also variable production costs to be considered. These variable production costs include energy feedstock and utility costs, and other feedstock costs; all of which can be partially offset by income from any saleable byproduct of the hydrogen production process. For the large central hydrogen production plant, the energy feedstock is the industrial natural gas used by the natural gas fired-heaters for process heat, and the energy utility is the required grid industrial electricity used by the electrolysis process and to drive the process system components (pumps, compressors, etc.). Table 27 summarizes the energy feedstock and utility usage per kilogram of hydrogen produced (based on HYSYS analysis), and the resulting variable cost in the startup year (2020) based on H2A default unit energy costs (shown in Column 3 of Table 27). 
Table 27. Variable central plant operating energy feedstock and utility requirements and costs in startup year.

\begin{tabular}{|c|c|c|c|c|}
\hline Feedstock & $\begin{array}{c}\text { Lower } \\
\text { Heating } \\
\text { Value } \\
\text { (GJ/Nm3) }\end{array}$ & $\begin{array}{c}\text { Price in } \\
\text { Startup } \\
\text { Year } \\
(\$ 2010) / \mathrm{Nm} 3\end{array}$ & $\begin{array}{c}\text { Usage } \\
\text { (Nm3/kg H2) }\end{array}$ & $\begin{array}{c}\text { Cost in } \\
\text { Startup Year }\end{array}$ \\
\hline Industrial Natural Gas_metric & 0.036623406 & 0.210137349 & 1.4673 & $\$ 5,488,858$ \\
\hline Utility & $\begin{array}{l}\text { Lower } \\
\text { Heating } \\
\text { Value } \\
\text { (GJ/kWh) }\end{array}$ & $\begin{array}{c}\text { Price in } \\
\text { Startup } \\
\text { Year } \\
\text { (\$2010)/kWh }\end{array}$ & $\begin{array}{c}\text { Usage } \\
\text { (kWh/kg H2) }\end{array}$ & $\begin{array}{c}\text { Cost in } \\
\text { Startup Year }\end{array}$ \\
\hline Industrial Electricity_metric & 0.0036 & 0.055420854 & 32.8538 & $\$ 32,412,960$ \\
\hline
\end{tabular}

The other remaining variable cost is for demineralized water used to replace the water used in the electrolysis process, and to make up for the small amount of water that is not recovered from the hydrogen and oxygen product streams. Table 29 shows the cost of the demineralized water, the water used per kilogram of hydrogen produced (based on results from HYSYS), and the cost of the demineralized water feed in the startup year (2020).

Also shown in Table 29 is the value of the oxygen byproduct generated in the electrolysis process, the amount of oxygen generated per kilogram of hydrogen produced (from HYSYS), and the income generated in the startup year from the production of the oxygen. As noted earlier, in the lifecycle analysis the demineralized water usage represents a variable cost for the production process, and the oxygen byproduct represents variable income.

Table 28. Other central hydrogen production feed and byproduct cost/income.

\begin{tabular}{|c|c|c|c|}
\hline Feed/utility & $\$(2005) / g a l$ & Usage per kg H2 (gal) & Cost in Startup Year \\
\hline Demineralized Water & 0.0049962 & 2.3349 & $\$ 207,667$ \\
\hline & & & \\
\hline Byproduct & $\$(2005) / \mathbf{k g}$ & Production per kg H2 (kg) & Income in Startup Year \\
\hline Oxygen & 0.02 & 7.7629 & $\$ 2,763,846$ \\
\hline
\end{tabular}

The resulting total feedstock and utility costs, and byproduct credits in startup year of 2020 are shown in Table 29 for an assumed total yearly hydrogen production rate of 17,434,590 kg. The total energy feedstock cost is the yearly cost of the industrial natural gas used for process heat. The total utility cost is the yearly cost of the grid supplied industrial electricity; the total non-energy cost is the yearly cost of demineralized water used in the hydrogen production process; and the total byproduct credits represents the income from the yearly production of oxygen. The resulting total variable operating costs (including credit for the oxygen byproduct is of $\$ 36,677,943$. 
Table 29. Total feed, utility, and byproduct variable costs for large central hydrogen production plant.

\begin{tabular}{|l|r|}
\hline Total Non-Energy Feedstock Costs (\$/year), Demin. Water & $\$ 207,667$ \\
\hline Total Energy Feedstock Costs (\$/year), Ind. Natural Gas & $\$ 5,488,858$ \\
\hline Total Utility Costs (\$/year), Industrial Electricity & $\$ 32,620,627$ \\
\hline Total Byproduct Credits (\$/year), Oxygen & $\$ \$ 2,763,846)$ \\
\hline $\begin{array}{l}\text { Other variable operating costs (e.g. environ. surcharges, mat.,waste } \\
\text { treatment/disposal,) (\$/year) }\end{array}$ & $\$ 400,000$ \\
\hline CO $_{2}$ Sequestration O\&M costs and credits (\$/year) & $\$ 932,304$ \\
\hline Total Variable Operating Costs (\$/year) & $\$ 36,677,943$ \\
\hline
\end{tabular}

The remaining costs include SOE replacement costs, and other unplanned replacement costs. Because of the relatively simple and compact reference hydrogen production plant design, unplanned replacement costs were again assumed to be $2 \%$ of the total depreciable (direct and indirect) capital costs/year, or \$1,180,205/yr in (2010 \$). For the SOE module replacement costs, it was again assumed that $1 / 5$ of the SOE cells would be replaced each year (begin in2020), and that only the cost of the SOE cells $(\$ 50 / \mathrm{kW})$ would be considered, since the remaining module components (vessels, headers, etc.) would not be replaced. The resulting SOE replacement cost would be \$708,900/year (2010 \$).

With the above plant operating assumptions and financial information, the H2A spreadsheet performed a lifecycle cost analysis to predict hydrogen production costs with and without carbon sequestration, as discussed in the following section.

\subsubsection{Results of lifecycle analysis for large central hydrogen production plant}

The results of the H2A lifecycle cost analysis include a cash flow analysis for the plant construction and startup periods, and for the operating life of the plant. The resulting hydrogen production cost was determined based on the plant hydrogen-production capacity with and without carbon sequestration, and assuming an after-tax internal rate of return (IRR) of $10 \%$. The resulting cost components and total hydrogen production cost without carbon sequestration are summarized in Table 30.

Table 30. Hydrogen production cost summary for large central hydrogen production plant without carbon sequestration.

\begin{tabular}{|c|c|c|}
\hline \multicolumn{3}{|c|}{ Specific Item Cost Calculation } \\
\hline Cost Component & Cost Contribution $(\$ / k g)$ & $\begin{array}{c}\text { Percentage of } \mathrm{H} 2 \\
\text { Cost }\end{array}$ \\
\hline Capital Costs & $\$ 0.34$ & $12.5 \%$ \\
\hline Decommissioning Costs & $\$ 0.00$ & $0.0 \%$ \\
\hline Fixed O\&M & $\$ 0.32$ & $12.1 \%$ \\
\hline Feedstock Costs & $\$ 0.33$ & $12.3 \%$ \\
\hline Other Raw Material Costs & $\$ 0.01$ & $0.4 \%$ \\
\hline Byproduct Credits & $-\$ 0.16$ & $-5.8 \%$ \\
\hline $\begin{array}{l}\text { Other Variable Costs } \\
\text { (including utilities) }\end{array}$ & $\$ 1.84$ & $68.5 \%$ \\
\hline Total & $\$ 2.68$ & \\
\hline
\end{tabular}


To achieve an after-tax internal rate of return of $10 \%$ the required hydrogen price calculated using the $\mathrm{H} 2 \mathrm{~A}$ spreadsheet methodology is $\$ 2.68 / \mathrm{kg}$. This represents the price or cost of the hydrogen leaving the plant gate at $5 \mathrm{MPa}$ pressure. The major cost component was other variable costs, which is the cost of the industrial grid electricity used in the hydrogen production process, representing $68.5 \%$ of the total hydrogen production cost. Capital costs were $12.5 \%$ of total costs followed by fixed O\&M costs and feedstock costs (natural gas), representing $12.1 \%$ and $12.3 \%$ of the total hydrogen production cost, respectively. The demineralized water (raw material) made up the remaining $0.4 \%$ of total hydrogen production costs. These costs were partially offset by the value of the oxygen byproduct produced in the HTE process, which reduced the hydrogen production costs by $\$ 0.16 / \mathrm{kg}$.

If carbon sequestration is included in the $\mathrm{H} 2 \mathrm{~A}$ analysis, additional capital, O\&M and energy costs associated with the carbon sequestration process must be added to the total hydrogen costs. These approximate additional costs represent the cost of the sequestration process $\left(\mathrm{CO}_{2}\right.$ pipelines, injection well(s), compressors, etc.), but do not include carbon capture capital and operating costs. The costs associated with the carbon sequestration process are summarized in Table 31 . The major cost component in this case is the capital costs, which as noted earlier, amount to $\$ 32,690,093$ or $78 \%$ of the total cost per ton of $\mathrm{CO}_{2}$ sequestered (Table 31).

Table 31. Summary of carbon sequestration costs for central hydrogen production plant.

\begin{tabular}{|l|c|c|}
\hline \multicolumn{3}{|c|}{ Approximate Carbon Sequestration Costs* } \\
\hline Cost Component & $\begin{array}{c}\text { Cost } \\
\text { Contribution }(\$ / \\
\text { kg H2) }\end{array}$ & $\begin{array}{c}\text { Cost } \\
\text { Contribution } \\
\text { (\$/ tonne CO2 } \\
\text { Sequestered) }\end{array}$ \\
\hline Capital Costs & $\$ 0.25$ & $\$ 91.40$ \\
\hline O\&M Cost & $\$ 0.05$ & $\$ 19.60$ \\
\hline Energy Cost & $\$ 0.02$ & $\$ 5.70$ \\
\hline Total & $\$ 0.32$ & $\$ 116.70$ \\
\hline \multirow{2}{*}{$\begin{array}{l}\text { *Carbon sequestration costs presented in this table do not } \\
\text { include carbon capture capital and operating costs. }\end{array}$} \\
\hline
\end{tabular}

When the above carbon sequestration costs are added to the hydrogen production costs, the resulting total hydrogen production cost and cost components are shown in Table 32. Variable costs, which include utility costs, again represent the largest cost component at $\$ 1.91 / \mathrm{kg}$ or $61.8 \%$ of the total cost of hydrogen production. Capital costs are again the second largest cost component, and are higher because they include the capital cost of the carbon sequestration equipment. Fixed O\&M and feedstock costs represent $11.8 \%$ and $10.7 \%$ of total costs, respective; followed by raw material costs at $0.4 \%$ of total costs. 
Table 32. Hydrogen production cost summary for large central hydrogen production plant with carbon sequestration.

\begin{tabular}{|c|c|c|}
\hline \multicolumn{3}{|c|}{ Specific Item Cost Calculation } \\
\hline Cost Component & Cost Contribution (\$/kg) & $\begin{array}{c}\text { Percentage of } \mathrm{H} 2 \\
\text { Cost }\end{array}$ \\
\hline Capital Costs & $\$ 0.63$ & $20.4 \%$ \\
\hline Decommissioning Costs & $\$ 0.00$ & $0.0 \%$ \\
\hline Fixed O\&M & $\$ 0.36$ & $11.8 \%$ \\
\hline Feedstock Costs & $\$ 0.33$ & $10.7 \%$ \\
\hline Other Raw Material Costs & $\$ 0.01$ & $0.4 \%$ \\
\hline Byproduct Credits & $-\$ 0.16$ & $-5.0 \%$ \\
\hline $\begin{array}{r}\text { Other Variable Costs } \\
\text { (including utilities) }\end{array}$ & $\$ 1.91$ & $61.8 \%$ \\
\hline Total & $\$ 3.08$ & \\
\hline
\end{tabular}

\section{CONCLUSIONS}

Detailed results of system evaluations and lifecycle cost analyses performed for several different commercial-scale high-temperature electrolysis (HTE) hydrogen production plant configurations were presented. The optimized designs described in this report are based on HYSYS process analyses software that included realistic representations of fluid conditions and component efficiencies and operating parameters for each of the HTE hydrogen production configurations analyzed. The detailed results of the HYSYS analyses were then used as input to the H2A lifecycle cost analyses which included both central plant designs for large-scale hydrogen production $(50,000 \mathrm{~kg} /$ day or larger) with and without carbon sequestration and forecourt plant designs for distributed production and delivery at about $1,500 \mathrm{~kg} /$ day. The assumed reference design for this study was a 1,500 kg/day forecourt HTE hydrogen production and distribution facility that operated in the thermal-neutral electrolysis mode using industrial natural gas for process heat and industrial grid electricity to power the electrolysis process and drive system component (compressors, circulators, etc.). Variations from this reference design, that included replacing the natural gas process heaters with electric resistance heaters, and operating the electrolyzer below the thermalneutral voltage were then evaluated. The size of the reference plant configuration was then increased to $50,000 \mathrm{~kg} /$ day, and H2A lifecycle analyses were performed for a central plant design with and without carbon sequestration. The resulting operating conditions and lifecycle costs for these different plant configurations are summarized in the Table 32 below. 
Table 33. Summary of HTE hydrogen production plant operating conditions and life cycle analyses.

\begin{tabular}{|c|c|c|c|c|c|}
\hline & $\begin{array}{l}\text { Reference } \\
\text { forecourt } 1500 \\
\mathrm{~kg} / \text { day } \mathrm{H}_{2} \\
\text { production } \\
\text { plant }\end{array}$ & $\begin{array}{l}\text { All electric } \\
\text { forecourt } \\
1500 \mathrm{~kg} / \text { day } \mathrm{H}_{2} \\
\text { production } \\
\text { plant }\end{array}$ & $\begin{array}{l}\text { Reference } \\
1500 \mathrm{~kg} / \text { day } \mathrm{H}_{2} \\
\text { forcourt } \\
\text { production } \\
\text { plant operating } \\
\text { below thermal- } \\
\text { neutral }\end{array}$ & $\begin{array}{l}50,000 \mathrm{~kg} / \text { day } \\
\mathrm{H}_{2} \text { central } \\
\text { production } \\
\text { plant without } \\
\text { carbon } \\
\text { sequestration }\end{array}$ & $\begin{array}{l}50,000 \mathrm{~kg} / \text { day } \\
\mathrm{H}_{2} \text { central } \\
\text { production } \\
\text { plant with } \\
\text { carbon } \\
\text { sequestration }\end{array}$ \\
\hline $\begin{array}{l}\text { Operating } \\
\text { capacity factor, } \\
\%\end{array}$ & 85.2 & 85.2 & 85.2 & 95 & 95 \\
\hline $\begin{array}{l}\text { Plant design } \\
\text { capacity, } \\
\text { kg/day }\end{array}$ & 1500 & 1500 & 1500 & 50,280 & 50,280 \\
\hline $\begin{array}{l}\text { Plant output, } \\
\text { kg/day }\end{array}$ & 1278 & 1278 & 1278 & 47,766 & 47,766 \\
\hline $\begin{array}{l}\text { Assumed start } \\
\text { up year }\end{array}$ & 2020 & 2020 & 2020 & 2020 & 2020 \\
\hline Plant life, years & 20 & 20 & 20 & 40 & 40 \\
\hline $\begin{array}{l}\text { Electrolyzer } \\
\text { LHV } \\
\text { efficiency, \% }\end{array}$ & 97.55 & 97.43 & 119.4 & 97.45 & 97.45 \\
\hline $\begin{array}{l}\text { Facility LHV } \\
\text { efficiency, \% }\end{array}$ & 69.48 & 78.07 & 33.06 & 69.43 & 69.43 \\
\hline $\begin{array}{l}\text { Total natural } \\
\text { gas cost in } \\
\text { startup year, \$ }\end{array}$ & $\$ 143,858$ & $\$ 0$ & $\$ 770,155$ & $\$ 5,488,858$ & $\$ 5,488,858$ \\
\hline $\begin{array}{l}\text { Total electric } \\
\text { cost in startup } \\
\text { year, \$ }\end{array}$ & $\$ 848,641$ & $\$ 1,092,409$ & $\$ 552,378$ & $\$ 32,412,960$ & $\$ 32,412,960$ \\
\hline $\begin{array}{l}\text { Total oxygen } \\
\text { byproduct } \\
\text { income in } \\
\text { startup year, \$ }\end{array}$ & $\$ 73,188$ & $\$ 72,450$ & $\$ 71,934$ & $\$ 2,753,846$ & $\$ 2,753,846$ \\
\hline $\begin{array}{l}\text { Total } \\
\text { production cost } \\
\text { of } \mathrm{H}_{2} \$ / \mathrm{kg}\end{array}$ & $\$ 3.12$ & $\$ 3.26$ & $\$ 4.89$ & $\$ 2.68$ & $\$ 3.08$ \\
\hline $\begin{array}{l}\text { Total prod. and } \\
\text { distribution } \\
\text { cost of } \mathrm{H}_{2}\end{array}$ & $\$ 4.87$ & $\$ 5.01$ & $\$ 6.64$ & -- & -- \\
\hline
\end{tabular}


Total H2A calculated hydrogen production costs for the reference $1,500 \mathrm{~kg} / \mathrm{day}$ forecourt hydrogen production plant were $\$ 3.12 / \mathrm{kg}$. The all-electric plant design using electric resistance heaters for process heat, and the reference design operating below the thermal-neutral voltage had calculate lifecycle hydrogen productions costs of $\$ 3.26 / \mathrm{kg}$ and $\$ 4.89 / \mathrm{kg}$, respectively. Because of its larger size and associated economies of scale, the $50,000 \mathrm{~kg} /$ day central hydrogen production plant was able to produce hydrogen at a cost of only $\$ 2.68 / \mathrm{kg}$ without considering the cost of carbon sequestration. When the cost of carbon sequestration is included, the production cost of hydrogen for the $50,000 \mathrm{~kg} /$ day central hydrogen production plant increased to $\$ 3.08 / \mathrm{kg}$.

\section{REFERENCES}

1. T. Ramsdem, D. Steward, and J. Zuboy, "Analyzing the Levelized Cost of Centralized and Distributed Hydrogen Production Using the H2A Production Model, Version 2", NREL/TP-56046267, September 2009

2. J. Ivy, " Summary of Electrolytic Hydrogen Production", Milestone Completion Report, NREL/MP-560-36734, September 2004

3. http://matche.com/EquipCost

4. http://www.cheresources.com/uexchangers.shtml

5. H. P. Loh and Jennifer Lyons, "Process Equipment Cost Estimation - Final Report", DOE/NETL2002/1169

6. K. M. Guthrie, " Data and Techniques for preliminary Capital Cost Estimating", Chemical Engineering, March 1969

7. Dominion Engineering, Inc., "Preliminary Evaluation of 160 TPD HTSE Hydrogen Plant Capital Costs", M-6917-00-01, Rev. 0 DRAFT A, August 2010

8. E. A. Harvego, M. G. McKellar, M. S. Sohal, J. E. O’Brien, J. S. Herring, "Economic Analysis of the Reference Design for a Nuclear-Driven High- Temperature-Electrolysis Hydrogen Production Plant", INL/EXT-08-13799, January 2008 